\title{
Regulating Investors Not Issuers: A Market-Based Proposal
}

\author{
Stephen Choi $\dagger$
}

\section{TABLE OF CONTENTS}

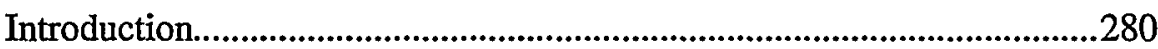

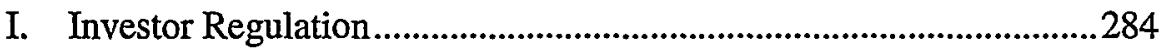

A. Information-Based Regulation ..................................................284

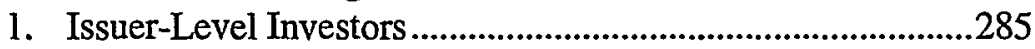

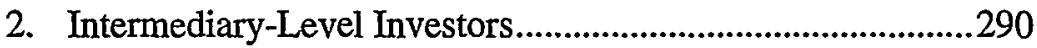

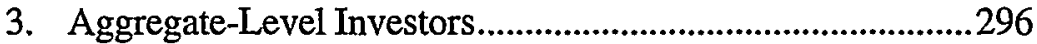

4. Unsophisticated Investors .......................................................300

5. Investor Regulation and the Efficient Markets

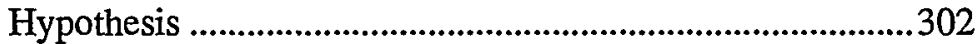

6. Comparison to the Present Regime.....................................304

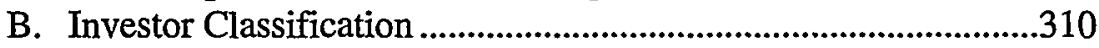

1. Mandatory Licensing ...............................................................310

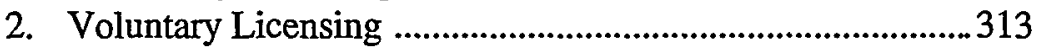

3. Hybrid Licensing Schemes ......................................................318

C. Third-Party Regulations .............................................................319

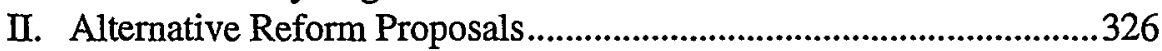

A. The SEC's Aircraft Carrier Release .........................................326

B. Other Market-Based Proposals...................................................331

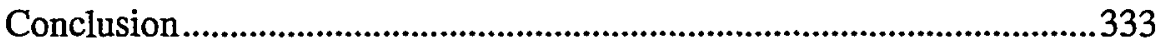

Copyright $\odot 2000$ California Law Review, Inc.

$\dagger$ Professor of Law, School of Law, Umiversity of California, Berkeley (Boalt Hall). E-mail comments to: schoi@law.berkeley.edu. Special thanks to Un Kyung Park. Thanks for helpful comments to James Cox, Jesse Fried, Andrew Guzmán, Dan Klerman, Chris Kutz, Adam Pritchard, Ronald Mann, Eric Posner, Mark Ramseyer, Eric Talley, and Omri Yadlin. 


\title{
Regulating Investors Not Issuers: A Market-Based Proposal
}

\author{
Stephen Choi
}

The present securities regulatory regime in the United States focuses on the protection of investors. Investor protection, in turn, leads to a robust capital market. The federal government accomplishes its goal of investor protection through the registration and direct regulatory control of issuers, intermediaries, and self-regulatory organizations in the securities markets. The Article contends that this regulatory approach is ill advised. Rather, the Article argues that regulators should instead regulate investors. Although against current wisdom, a securities regime that regulated investors would allow regulators to take a more market-driven approach toward investor protection, resulting in a less paternalistic regime. For those investors with good information on issuers in the market, for example, no mandatory regulations are necessary. Rather investors will contract for desired protections; those market participants failing to provide valued protections will receive less for their securities or services. As a result, market participants will voluntarily provide desired protections. The Article, therefore, proposes to classify investors based on their informational resources. Such classification frees those investors able to protect themselves to engage in a wide variety of investments while allowing regulators to focus their resources on investors less well equipped.

\section{INTRODUCTION}

Securities regulation in the United States revolves around investor protection. Unscrupulous promoters, for example, may seek to defraud investors by convincing them to put their money into worthless investments. Alternatively, promoters may attempt to guide investors into investments where the risks are both high and difficult to assess. When protected, investors gain the necessary confidence to purchase securities, in theory generating a robust capital market. From this simple premise, Congress and the Securities and Exchange Commission (SEC) put forth a vast number of regulations governing issuers, securities exchanges, brokerdealers, and other market participants in the name of investor protection. ${ }^{1}$ Although aimed at securities market participants, such regulations also

1. This Article uses the term "market participants" to refer broadly to issuers, exchanges, broker-dealers, investment advisors, and other intermediaries in the securities markets. 
restrict the choices available to investors, resulting in the indirect regulation of investors themselves.

For example, the Securities Act of 1933 (Securities Act) ${ }^{2}$ forces issuers conducting a public offering to refrain from inaking offers of securities until they file a registration statement with the SEC and to delay sales until the registration statement becomes effective. ${ }^{3}$ As a result, investors are unable to purchase securities of companies choosing not to engage in a public offering unless the investors qualify to participate in a far inore restrictive private placernent of securities. ${ }^{4}$ Similarly, under the Securities Exchange Act of 1934 (Exchange Act) ${ }^{5}$ securities exchanges as well as national securities associations, of which the National Association of Securities Dealers (NASD) is presently the sole association, must register with the SEC as self-regulatory organizations (SROs) ${ }^{6}$ The direct consequence of SRO registration is that investors may not interact and trade at the forum of their choice until the SEC grants its approval. ${ }^{7}$ Most

2. $\quad 15$ U.S.C. $\$ \$ 77 \mathrm{a}$ to $77 \mathrm{z}-3$ (1994).

3. See Securities Act $\S 5(c), 15$ U.S.C. $\$ 77 \mathrm{e}(\mathrm{c})$ (prohibiting any oral or written offers prior to the filing of the registration statement); see also Securities Act $\S 5(\mathrm{a}), 15$ U.S.C. $\S 77$ (e)(a) (prohibiting sales until after the registration statement becomes effective). The registration statement is the formal statutory document issuers must file with the SEC when selling securities to the public. For most domestic companies, the rcgistration statement consists of information contained on either Form S-1, S-2, or S-3 of the Securities Act. See Securities Act Forms S-1, S-2, \& S-3, 17 C.F.R. \$§ 239.1113 (1999).

4. Among other things, investors purchasing securities through most private placements are unable to resell their securities immediately. Instead, investors typically must wait until a safe harbor provides for resales. For example, most investors may resell their private placement securities under Rule 144 of the Securities Act after a one-year holding period. See Securities Act Rule 144, 17 C.F.R. § 230.144. Furthermore, not all mvestors are qualified to participate in private placements. Rule 506 of the Securities Act, for example, allows issuers to sell a private placement to no more than 35 nonaccredited purchasers. The SEC defines accredited investors to include certain financial institutions and, in the case of individuals, investors with an annual income over $\$ 200,000$ for each of the two most recent years or a net worth over $\$ 1$ million. See Securities Act Rule 501(a)(5-6), 17 C.F.R. \$§ 230.501(a)(5-6). In addition, under Rule 506 all purchasers inust be sophisticated in their investment knowledge either mdividually or through a purchaser representative. See Securities Act Rule 506(a), 17 C.F.R. $\$ 230.506(a)$.

5. 15 U.S.C. $\$ \$ 78 \mathrm{a}-78 \mathrm{~mm}$.

6. See Exchange Act $§ 15 A, 15$ U.S.C. $\$ 780-3$ (1994).

7. In addition, in recent years alternative trading systems providing new arenas for investors to interact and match their order flows have arisen. For example, electronic matching systems provide a forum for participants to indicate firm, priced buy, or sell orders to other participants and, in soine systems, to execute these orders automatically. Instinet, a subsidiary of Reuters Holdings PLC, is a matching alternative trading systcm. Instinet operates in over 30 countries and is registered with the SEC as a broker-dealer. See Instinet Corporation (visited Oct. 31, 1999) <http://www.instinet.com/ home.html>.

In response to the growth of alternative trading systems (ATSs), the SEC recently adopted new rules governing such systems. See SEC, Regulation of Exchanges and Alternative Trading Systems, Release No. 34-40760; File No. S7-12-98 (Dec. 8, 1998). Under the new rules, most ATSs face a choice between either broker-dealer or exchange regulation. See id. 
broker-dealers $^{8}$ and investment advisors, ${ }^{9}$ in turn, must register with a national securities association or directly with the SEC. ${ }^{10}$ Investors are effectively prohibited from receiving advice from the intermediary of their choice without obtaining regulatory approval.

In many circumstances, the impact of securities regulation on the range of options available to investors is justified. Some investors lack the necessary information or expertise to make value-maximizing decisions; the imposition of regulatory oversight may increase the confidence of such investors and, thereby, their willingness to invest in the markets. This Article argues that, despite these benefits, the current regime is at best inconsistent and often flawed because of its lack of focus on the impact of regulation on the choices available to investors. If investor protection is the goal, why not structure regulations directly around investors? Recognizing the investor protection rationale behind the regulation of issuers, exchanges, and other market participants provides insight into when the market may work better than regulation to protect investors.

For example, regulation of any sort may be unnecessary for rational investors with good information on the risks and returns offered through particular issuers. These investors will price privately-supplied investor protections, paying more for securities from issuers offering valued protections. Market participants, in turn, will have an incentive to adopt investor safeguards to the extent the increase in the amount investors are willing to pay exceeds the cost of the protections. ${ }^{11}$ The same incentive exists for all securities market participants that deal with rational investors, including issuers, broker-dealers, mutual funds, and exchanges. Although

8. Section 3(a)(4) of the Exchange Act defines a "broker" as "any person engaged in the business of effecting transaetions in securities for the account of others, but does not include a hank." Exchange Act $\$ 3(a)(4), 15$ U.S.C. $\$ 78 c(a)(4)$. Section 3(a)(5) of the Exchange Act, in turn, defines a "dealer" as:

any person engaged in the business of buying and selling securities for his own account, through a broker or otherwise, but does not include a bank, or any person insofar as he huys or sells a security for his own account, either individually or in some fiduciary capacity, but not as a part of a regular business.

15 U.S.C. $\$ 78 \mathrm{c}(\mathrm{a})(5)$.

9. Section 202(a)(11) of the Investment Advisers Act defincs an "investment adviser" as any person who, for compensation, engages in the business of advising others, either directly or through publications or writings, as to the value of securities or as to the advisability of investing in, purchasing, or selling securities, or who, for compensation and as part of a regular business, issues or promulgates analyses or reports concerning securities.... Investment Advisers Act $\$ 202(a)(11), 15$ U.S.C. $\$ 80 b-2(a)(11)(1994)$.

10. See Exchange Act $\$ 15$ (a), 15 U.S.C. $\$ 78$ o(a). In addition, broker-dealers that seek to trade on a securities exchange are required to register as members with the exchange. See, e.g., N.Y.S.E. Guide (CCH) I 2054 (Aug. 11, 1978) (restricting nonmembers from making or accepting bids and offers, or consummating transactions on the NYSE). Nonmember broker-dealers, nevertheless, may execute a trade through the NYSE using the Intermarket Trading System. See infra note 133 and accompanying text.

11. See, e.g., Stephen J. Choi \& Andrew T. Guzmán, National Laws, International Money: Regulation in a Global Capital Market, 65 FoRDHAM L. REv. 1855, 1864-65 (1997). 
different participants pose varying risks to investors, rational investors can price these risks accordingly in their investment decisions. Thus, there is a strong argument for reınoving the many layers of regulation from market participants that deal with these investors.

From this insight, this Article proposes to shift the focus of regulation directly onto mvestors and away froin other securities market participants, allowing regulators to abolish nost of the Securities Act and the Exchange Act, as well as much of the Investment Advisors Act of $1940,{ }^{12}$ and the Investment Company Act of $1940 .{ }^{13}$ Changing the focus of regulation to investors rather than issuers or intermediaries would allow regulators to provide protections tailored to the informational needs of specific segments of investors. ${ }^{14}$ Of course, not all investors internalize the benefit from voluntary investor protections. Investors lacking information on the actual protections that issuers adopt will fail to value such protections. However, investors might have good information on other types of market participants. For example, an investor who lacks information on individual issuers might have good information on intermediaries, such as brokerdealers, mutual funds, or exchanges. Such investors will select intermediaries that offer desired investor protections. Regardless of their specific capital market functions, intermediaries will attract the business of these investors by voluntarily adopting value-1naximizing protections, contracting with other intermediaries to supply desired investor protections at a lower cost and screening for appropriate investinents. Accordingly, an alternative regulatory approach should take into account investors' knowledge of market participants other than issuers.

Part I delineates this Article's argument for regulating investors based on the level of information investors possess on securities inarket participants. This Part also proposes to license investors; much like a pilot's license, investors would need an investment license to deal with particular types of capital market participants. Part II applies this Article's arguments to the present regime goverming issuers and intermediaries and assesses alternative reform proposals.

12. 15 U.S.C. $\$ 80 \mathrm{~b}$.

13. Id. $\$ 80$ a.

14. Relatively few prior works have examined the question of investor sophistication. See generally C. Edward Fletcher, III, Sophisticated Investors Under the Federal Securities Laws, 1988 DUKE L. J. 1081 (discussing the distinctions the securities laws make between sophisticated and unsophisticated imvestors); Geoffrey B. Goldman, Note, Crafting a Suitability Requirement for the Sale of Over-The-Counter Derivatives: Should Regulators "Punish the Wall Street Hounds of Greed"?, 95 CoLum. L. Rev. 1112 (1995) (proposing to impose suitability requirements on dealers in the OTC derivatives market depending on the sophistication of investors). 


\section{INVESTOR REGULATION}

The goal of investor protection pervades the securities laws. Current securities laws are designed to force market participants to disclose necessary information to investors. However, this focus on the supply side of the securities inarket may disadvantage investors, especially those who do not require such disclosures. This Part argues that investors might be better "protected" by laws and regulations that focus directly on investors. Part I.A begins by describing a possible investor-focused regulatory regime. Part I.B then discusses two alternative mechanisms to classify investors: mandatory licensing schemes and voluntary self-licensing. Finally, Part I.C discusses the problem of third-party effects arising from securities market decisions.

\section{A. Information-Based Regulation}

The readiness of inarkets to provide valued investor protections turns on investor knowledge. For example, where investors are uninformed about protections adopted in the inarket, they will not pay a premium for such protections. Market participants will then fail to provide these protections. Because of the imiportance of information for market-based investor protection, this Section divides investors into categories based on investor knowledge of securities market participants.

For expositional purposes, this Article posits four groups of investors: (1) investors informed at the level of individual issuers ("issuerlevel" investors); (2) investors without information on particular issuers but informed about a range of securities intermediaries ("intermediarylevel" investors); (3) investors with information only on certain highlyvisible market participants, including nationally known individual intermediaries ("aggregate-level" investors); and (4) investors without information on any securities market participants ("unsophisticated" investors). This Section proposes regulations that take into account the ability of investors within each group to contract for desired protections. ${ }^{15}$ Significantly, the precise division among investors is less important than the general principle that market forces may supplant securities regulation for specific classes of investors.

15. Some investors may wear several different hats. A mutual fund, for example, may act as an investor when deciding where to place capital under its management. As such, the mutual fund operator will have to receive an issuer-level license as to engage in issuer-level-only investments. On the other hand, the mutual fund also plays an imtermediary role, seeking to obtain and manage capital from other investors. As an intermediary, the mutual fund will be restricted under this Article's proposals along with other intermediaries in the range of investors with which they may make contact. For example, an actively inanaged mutual fund, as discussed later in this Article, is prohibited from raising capital from unsophisticated investors under the investor regulation regime. See infra Part 1.A.4 (describing restrictions placed on unsophisticated investors under this Article's investor regulation proposal). 


\section{Issuer-Level Investors}

This Article uses the term issuer-level investors to describe investors who are informed about issuer-specific risks and the various types of investor protections that issuers nay adopt. Where investors are informed, issuing coinpanies will internalize both the cost and benefit of investor protections. As a result, issuers will seek to maximize the joint welfare of issuers and investors. This Article proposes that securities of issuers that deal solely with issuer-level investors, both sold through primary offerings and traded in secondary market transactions, face no mandatory regulations. ${ }^{16}$ Under this proposal, such issuers would be able to sell securities freely to issuer-level investors without any mandatory information disclosure or antifraud liability. Likewise, issuer-level investors would be able to sell to other issuer-level investors without any mandatory regulatory protections. Instead, only those restrictions which the issuer voluntarily adopts for its securities, if any, would apply in the secondary market.

For example, consider Kate, an issuer-level investor deciding whether to invest in the public offering of Widget, Inc.'s common stock. Kate has good information on Widget and the value of regulatory as well as private market protections goverming Widget's offermg. Given such information, Kate will price Widget's offering accordingly. Where there is a high risk that Widget is engaged in fraud, Kate will decrease the amount she is willing to pay for Widget's stock. Conversely, Widget may voluntarily take actions to reduce the risk of fraud, choosing, for example, to issue securities with stringent warranties. Kate will then increase the amount she is willing to pay for Widget's securities based on the value of the warranties. As a result, Widget will internalize both the cost of fraud on imvestors as well as the benefit from adopting antifraud protections. ${ }^{17}$

Because issuers would internalize the benefit of value-maximizing investor protections, they would have an incentive to coordinate with other market participants in a way that serves the interests of all investors. For example, securities exchanges perform several valuable functions for investors such as providing liquidity and momitoring for insider trading and secondary market manipulation. ${ }^{18}$ Moreover, exchanges may enjoy

16. Companies, of course, may issue as many classes of securities as they want. This Article's investor regulation proposal does not turn on the number or type of securities a company offers. Rather, the proposal focuses on the particular investors that consider purchasing these securities.

17. See also Alan R. Paimiter, Toward Disclosure Choice in Securities Offerings, 1999 Colum. BUS. L. REV. 1, 21-23 (noting that "many issuers with securities traded on U.S. markets, not subject to full-blown registration requirements (particularly foreign issuers), have nonetheless chosen to disclose beyond what disclosure regulation requires").

18. See Jonathan Macey \& Hideki Kanda, The Stock Exchange as a Firm: The Emergence of Close Substitutes for the New York and Tokyo Stock Exchanges, 75 CoRNell L. Rev. 1007, 1010 (1990). Macey and Kanda note that exchanges provide listed companies with an off-the-rack set of default rules and help issuers signal their value to the market. See id. Companies value such services, paying annual fees to the NYSE that run as high as $\$ 500,000$. See id. at 1009 . 
economies of scale in providing these investor services, inducing issuers dealing with issuer-level investors to associate with an exchange in order to maximize the value to investors. ${ }^{19}$ Significantly, individual investors would not need to negotiate directly with issuers for protections. Instead, the desire to increase the price for issued securities will cause issuers to adopt desired investor safeguards governing both primary offerings as well as subsequent secondary market transactions. ${ }^{20}$

In a world with full information and without transaction costs, issuers and investors could costlessly specify and enforce contracts that allocate every possible risk between the issuer and the investor. However, contracts are not cost free: They take time and resources to draft, while enforcement is uncertain and may take years. Alternatively, issuers may attempt to assure investors of their quality through long-term reputations. ${ }^{21}$ Reputations, nevertheless, are difficult to maintain. For example, issuers may fail to develop a no-fraud reputation where the benefit from cheating on their reputation is high. Particularly for issuers coming to the capital markets for the first time, investors may not be able to eliminate the risk of fraud by relying on reputation alone. Thus, issuer-level investors may favor certain types of regulatory oversight as a supplement to contractual and reputational protections.

Without resorting to mandatory regulation, law makers possess several means to reduce the cost of private investor protections for issuer-level investors. In particular, this Article advocates allowing issuers to select the level of public regulation to which they will be subject-a system termed "self-tailored regulation." Under a self-tailored regulatory system, issuers dealing with issuer-level investors could opt out completely from public regulation. Self-tailored regulation, however, would provide issuers more than the ability to avoid a specified legal regime. Where public regulatory bodies have a comparative advantage in remedying certain private market defects, market participants may decide for themselves their level of public liability and enforcement. ${ }^{23}$

19. Cf. Yakov Amihud \& Haim Mendelson, A New Approach to the Regulation of Trading Across Securities Markets, 71 N.Y.U. L. REv. 1411, 1445-46 (1996) (arguing that issuers will internalize the benefit liquidity provides investors and therefore should have the ability to determine the markets in which their securities may trade).

20. See Michael C. Jensen \& William H. Meckling, Theory of the Firm: Managerial Behavior, Agency Costs and Ownership Structure, 3 J. FIN. EcoN. 305 (1976).

21. See Benjamin Klein \& Keith B. Leffler, The Role of Market Forces in Assuring Contractual Performance, 89 J. PoL. ECoN. 615, 618-25 (1981).

22. See generally Stephen Choi, Market Lessons for Gatekeepers, 92 Nw. U. L. REv. 916, 95158 (1998) (describing the costs and benefits of a self-tailored regulatory system).

23. The self-regulatory decision could occur, for example, through a filing with the SEC or another regulatory agency. The agency could then work to disseminate the filing information to help investors in the market learn about a particular issuer's regulatory choices. 
In fact, self-tailored regulation makes it possible for issuers to select from a wide variety of liability regimes. Issuers could set the standard of liability they face at negligence, strict liability, or any intermediate standard of their choosing. Issuers could even elect to face criminal liability. Issuers could also select the type of enforcement they will face. For example, issuers could choose to have the SEC monitor transactions in the issuer's securities, opting imto a specified level of public enforcenient. To cover the costs of public enforcement, regulators could charge a fee to users of self-tailored regulation. ${ }^{24}$

Under this proposal, issuers would choose their level of liability and enforcement for both primary and secondary market transactions. Although issuers are not direct parties to secondary market transactions, they mcorporate the benefit of secondary market protections such as antifraud provisions. An antifraud provision, for example, may reduce the fear of investors in the secondary market that securities prices reflect false and misleading information. Investors, therefore, will be willing to pay n1ore for securities in the secondary market, leading imvestors purchasmg securities in the issuer's primary offering to mcrease their willingness to pay im response.

Issuers may also use self-tailored regulation to reduce the cost of frivolous suits. For example, plaintiffs' attorneys seeking to bring frivolous suits may target issuers with large financial resources. ${ }^{25}$ Through selftailored regulation, larger issuers may simply do away with private antifraud liability. Moreover, these issuers may be able to provide investors with other market-based assurances of the quality of their securities so that imvestors will not reduce their willinguess to pay for the issuers' securities. Some issuers may depend on their reputation for quality; other issuers may commit themselves to raising capital repeatedly from the capital market, providing the market with future chances at evaluating the issuers' performance. ${ }^{26}$ If issuers nevertheless choose to submit themselves to antifraud liability, they could also use the self-tailored regulatory regime to

24. Regulators are no different from other private providers of investor protection under selftailored regulation and should have freedom to charge for their services. The value of introducing the government into the private market lies with the ability of the government to provide certain protections at a lower cost than private actors, including, for example, criminal liability.

25. See D. Rosenberg \& S. Shavell, A Model in Which Suits Are Brought for Their Nuisance Value, 5 INT'L REv. L. \& ECON. 3, 3-4 (1985) (developing an economic model of nuisance suits based on the plaintiff's significant initial cost advantage in conducting a lawsuit); see also Janet Cooper Alexander, Do the Merits Matter? A Study of Settlements in Securities Class Actions, 43 STAN. L. REV. 497 (1991) (providing empirical evidence that settlements im securities fraud class actions are unrelated to merit); James Bohn \& Stephen Choi, Fraud in the New-Issues Market: Empirical Evidence on Securities Class Actions, 144 U. PA. L. REv. 903, 918-23 (1996) (providing evidence on the existence of frivolous lawsuits).

26. Cf. Frank H. Easterbrook, Two Agency-Cost Explanations of Dividends, 74 AM. EcoN. REv, 650,654 (1984) (arguing that frequent trips to capital markets for funding controls managerial moral hazard). 
adjust their liability regime to reduce the risk of frivolous actions. For example, issuers could eliminate class action suits and impose attorney feeshifting arrangements for antifraud suits.

Finally, self-tailored regulation would allow an issuer to bind investors who are not in direct privity to the issuer. For example, investors might engage in inanipulation of an issuer's securities in secondary market trading, artificially driving up the price of the security. To the extent an issuer elects for the government to monitor for market manipulation, regulators may then enforce penalties on manipulators not in any contractual relation with the issuer. Where investors as a group value antimanipulation protection, issuers will have an incentive to adopt such protections. ${ }^{27}$

There are several possible criticisms of a self-tailored regulatory regime. First, issuers that desire to defraud investors may abuse selftailored regulation and simply opt out of any liability. Nevertheless, adopting some level of liability and regulation will often be in the best interests of issuers. For example, rational mvestors may take a critical view of an issuer opting completely out of any regulatory protection and refuse to purchase the issuer's securities. This is particularly true for unknown issuers lacking alternative market-based assurances for investors. Even where rational investors choose to purchase securities, the price they pay would be discounted for the increased risk they face. ${ }^{28}$

Second, managers of issuers may face a conflict in determining an issuer's self-tailored regulation provisions. Although the issuer benefits froin committing itself to remain truthful in its offering, managers only pocket part of this benefit. For example, criminal liability may provide issuers a low-cost means of signaling credibly to the market that the company will disclose truthfully. Nevertheless, because managers themselves personally face the possibility of incarceration under criminal liability, they may choose not to incorporate such provisions into the issuer's self-tailored regulation. There are, however, solutions to managerial agency problems. For example, some issuers compensate managers with

27. As one alternative, issuers could seek to associate with securities exchanges that offer antimanipulation protections. Exchanges, moreover, may make it a contractual requirement that investors gaining access to the exchange agree not to manipulate stocks; if they breach that requirement, they face fines. Nevertheless, the effectiveness of monitoring by any particular exchange may be limited to the extent a manipulating investor conducts her trade off-exchange. See Marcel Kahan, Some Problems with Stock Exchange-Based Securities Regulation, 83 VA. L. REV. 1509, 151617 (1997) (arguing that exchanges may find it difficult to pass rules binding investors at large through private contract).

28. Cf. George L. Priest, A Theory of the Consumer Product Warranty, 90 YALE L.J. 1297, 130309 (1981) (describing how companies may use warranties to signal their value to consumers); Michael Spence, Consumer Misperceptions, Product Failure, and Producer Liability, 44 Rev. Econ. STUD. 561, 561-71 (1977) (providing an economic model of how companies may use guarantees to signal their quality to consumers). Issuers may also guarantee that a security's price will not fall below a certain minimum. For example, issuers may attach a put option to the shares tbey sell, allowing investors to force the issuer to buy back its shares at a certain fixed price. 
option contracts to align their interests more fully with owners. ${ }^{29}$ Moreover, at the time of incorporation, the founders of a firm will act to maximize the value offered to initial investors, balancing the cost of solutions to managerial agency problems against the benefit of self-regulatory liability in raising investor confidence. ${ }^{30}$

Third, there is a bait-and-switch problem. Management might implement shareholder devices such as proxy contest rules and takeover-friendly rules when issuing securities in order to obtain a high price for their shares, but then remove these protections once the offering is completed. However, to the extent investors value not only the presence of such protections but also their durability, managers will have an incentive to restrict midstream changes for a specified or indefinite period when they issue securities into the market. For example, an investor will heavily discount the value of a takeover-friendly regime when faced with the distinct possibility that managers will undo the regime immediately after the investor purchases stock in the company. Through self-tailored regulation, an issuer may opt into a mandatory time period during which specified regulations will apply to the issuer.

Finally, a fourth argument against self-tailored regulation is that it would result in too inany private regulators. Issuers may design their own separate regimes with respect to issuer-level investors. Not only may the resulting variety of investor protection devices cause confusion, but regulations that depend on economies of scale for effectiveness may fail. ${ }^{31}$ Investors may value standardized disclosure; standardized disclosure, for example, may reduce the cost of investors in reading and analyzing disclosures across many different firms. If Exxon decides to disclose its financials for two-year periods beginning on May 1 of each year, and Amoco discloses for sixteen-month periods beginning on January 1 of each year, investors may have difficulty comparing the two companies. Eventually, however, the Internet may eliminate the standards problein altogether, making the format of disclosure irrelevant. Companies and other sources of information could provide raw information on financials, business operations, and executive compensations, among other investment-related data.

29. See David Yermack, Good Timing: CEO Stock Option Awards and Company News Announcements, 52 J. FIN. 449 (1997) (listing several companies with CEO stock option-based compensation).

30. Thanks to Omri Yadlin for helpful insight on this point.

31. For example, regulators faced with a myriad of self-tailored regulation provisions may lack the ability to develop scale economies in detecting violations. Courts may also become overwhelined by the range of possible self-regulatory provisions. See generally Michael Klausner, Corporations, Corporate Law, and Networks of Contracts, 81 VA. L. REv. 757, 772-815 (1995) (discussing the problem of network externalities in corporate contract terms). 
Through computerized search engines, investors could then access this raw data and reassemble the data into any format they desire. ${ }^{32}$

Uncoordinated private regulation may also result in too little innovation once a standard has arisen in the market. Although an entire segment of the market may value some competing form of disclosure, for example, no single company has full incentive to experiment in creating this new form to the extent the company would not incorporate the benefit of the form to others in the market.

Although these network externalities could undermine the desirability of self-tailored regulation, regulators could take steps to reduce standardization problems. Law makers may make public the investor protections submitted under a self-tailored regulatory regime, reducing the cost to all market participants of privately contracting for particular standardized protections. Regulators may also "seed" the market through the use of an initial menu of default options from which issuers may select. ${ }^{33}$ Issuers seeking a customized level of protection could start with one menu default and adjust incrementally to their desired level of protection. In this way, self-tailored regulation might spawn sets of relatively standardized publicly available procedures covering a range of investor protection devices and catering to different segments of the market.

\section{Intermediary-Level Investors}

Where investors are not informed at an issuer-level, either directly or through an efficient market, issuers will lack a direct market incentive to adopt value-maximizing investor protections. ${ }^{34}$ However, lack of issuerlevel information alone does not justify mandatory regulation. Instead, so long as issuers deal with investors associated with appropriate intermediaries, the intermediaries will act for the investors in screeming investments and in negotiating with issuers for value-maximizing protections. For example, an investor may rely on a securities exchange to screen listed companies and momitor their market for market manipulation and other threats to investors. ${ }^{35}$ Likewise, actively managed mutual funds may screen

32. See, e.g., Rachel Witmer, Accounting: SEC's Wallman Describes View of Technology's Impact on Accounting, 28 SEC. REG. L. REP. 1531 (Dec. 13, 1996).

33. See Klausner, supra note 31 , at $826-41$.

34. For example, suppose an issuer is deciding whether to implement an investor protection device at a cost of $\$ 5$ per share that would raise the value to investors of the issuer's securities by $\$ 10$ per share. To the extent investors do not recognize or value this protection, however, investors will fail to pay any more for the securities, leading the issuer to forego the investor protection device.

35. Through their listing requirements, for example, exchanges screen companics based on a variety of factors including net assets and capitalization. The New York Stock Exchange (NYSE) requires listed companies to meet minimum capitalization, net income, and number of shareholder requirements. See NYSE (visited Oct. 31, 1999) <http://www.nyse.com>. Exchanges had established their own listing requirements long before the passage of the federal securities laws. The NYSE, for example, mandated the submission of balance sheets and income statements by listed corporations. As 
investments for their investor clientele, providing both investment expertise and diversification. This Article refers to investors with knowledge on a range of securities inarket intermediaries as intermediary-level investors. This Article proposes requiring intermediary-level investors to associate with a securities inarket intermediary for all their transactions. ${ }^{36}$

Intermediaries, in turn, will choose to protect investors to the extent investors value such services. Investors may compensate an intermediary either directly in the form of fees or indirectly through the purchase of other services from the intermediary. For example, a securities exchange may receive coinpensation through greater transaction volume and listing fees from issuers attracted to the exchange because of the high volume of investor activity.

Consider Sarah, an intermediary-level investor. Sarah lacks knowledge on specific companies in the stock market; nevertheless, she follows the reputation and investor protections of several brokers. She selects Ameritrade to act as her broker, paying a premium for Ameritrade's highquality reputation for protectimg investors. In turn, Ameritrade, to maintain its reputation and the corresponding increased fees it receives, will recommend securities-based on Ameritrade's own research-that provide a risk-return combination suitable to Sarah's financial position. To further assure Sarah of an investment's suitability, Ameritrade could, at its own discretion, provide varying contractual warranties as to the suitability of its recommended securities. ${ }^{37}$

General financial knowledge is only marginally significant for interinediary-level investors. This is because these investors can rely on other capital inarket participants to analyze financial information and provide investor protections. Thus, what distinguishes this category of investors is their knowledge of the range of different participants and the protections they provide. In addition, the type of information an investor requires to assess the value of an intermediary in providing investor protection is

well, just prior to the passage of the federal securities law, all NYSE companies were regularly audited. See George J. Benston, Required Disclosure and the Stock Market: An Evaluation of the Securities Exchange Act of 1934, 63 AM. EcoN. REv. 132, 133 (1973).

36. The securities laws generally do not require the presence of an intermediary in a transaction. In several places, however, the securities laws presume such a presence. Section 11(a), for example, places antifraud liability on underwriters associated with a public offering. See Securities Act $\S 11$ (a), 15 U.S.C. § 77k (1994). In other places, the SEC imposes obligations which make it likely that an intermediary will take part in a transaction. For example, Rule 502(c) prohibits general solicitation of investors for private placements under Rule 505 and 506 of Regulation D of the Securities Act. To get around the prohibition against general solicitation, issuers must hire broker-dealers specializing in collecting lists of qualified investors ahead of time. See Donald C. Langevoort, Angels on the Internet: The Elusive Promise of "Technological Disintermediation" for Unregistered Offerings of Securities, 2 J. SMall \& EMERging Bus. L. 1, 4-12 (1998).

37. Through self-tailored regulation, as put forth in this Article, Ameritrade may also employ public standards of liability for suitability as well as public enforcement. See supra note 24 and accompanying text. 
oftentimes less time-consnming and complex to assess than that required for a specific company. For example, investors who work through brokers need not research every possible investment opportunity that the broker suggests, but rather must research only the reputation and expertise of the particular broker. In contrast, to assess a particular issuer, investors must look at the issuer's financials and business information in addition to valuing any investor protection devices. Investors must also compare the securities of a particular company against a myriad of other possible investment vehicles. ${ }^{38}$ Of course, investors may attempt to rely on an issuer's reputation. However, for issuers whose securities do not trade in an efficient market, little public information may exist. ${ }^{39}$ To the extent intermediaries are well known and have more repeat interactions with the capital markets than less-followed issuers, investors will face a lower cost in determining a particular intermediary's reputation. A regulatory regime that focuses on investors who are informed on a spectrum of market intermediaries but not on individual issuers, therefore, will apply to a wider percentage of investors. Issuers then face a choice: They may choose to deal with only issuer-level investors or with intermediary-level investors associated with an intermediary.

The type of intermediary imvestors choose does not matter. Intermediary-level investors may associate with an investment company or advisor, a broker-dealer, an exchange, or any combination of these intermediaries. So long as the investor has good intermediary-level information, the investor will select intermediaries providing the investor protection package the investor desires. Although intermediaries provide different functions to the capital market and pose different risks to investors, because any one intermediary is potentially connected through contract with issuers and other intermediaries, each can negotiate for a range of investor protections provided through other market participants. Thus, from an investor protection point of view, no rationale exists to differentiate among intermediaries.

Consider Sarah again. She selects Ameritrade to act as her broker, paying a premium for Ameritrade's high-quality reputation for protecting investors. Ameritrade, however, may not be the lowest-cost provider of desired investor protections; in particular situations, an issuer may provide an investor protection at a lower overall expense. To maintain its reputation and the corresponding increased fees it receives, Ameritrade will direct Sarah to securities of issuers employing value-maximizing investor

38. See Homer Kripke, The SEC, the Accountants, Some Myths and Some Realities, 45 N.Y.U. L. REv. 1151, 1164-70 (1970) (noting that most investors do not directly read information disclosures on companies but rather rely on securities professionals).

39. Investors that deal with issuers that trade on an efficient market are deemed issuer-level investors with respect to the efficient market issuer. See infra Part I.A.5. 
protections. For example, Sarah may desire a certain level of protection agamst market manipulation and insider trading. Rather than provide such protection directly, Ameritrade may send Sarah's orders only to an exchange or alternative trading forum that both enjoys a comparative advantage in providing such protections and actually does so. More generally, Ameritrade will have an incentive to choose among other market participants to minimize investment risks while maximizing returns; Sarah will pay more for the services of Ameritrade as a result.

Although intermediaries would have incentives to adopt valuemaximizing protections under this proposal, there may be limits to their ability to protect investors efficiently and effectively. In particular, intermediaries may find it prohibitively expensive to provide contractual protections due to transaction costs and uncertainties in how a court may apply the protections. As well, intermediaries may fail to develop a good reputation where the benefit from cheating on their reputation is high. Those intermediaries that do successfully commit themselves to acting faithfully may need a large market share to do so, leading to super-competitive profits and high fees for investors. ${ }^{40}$ An intermediary with a large market share that suffers a loss im reputation stands to lose a much greater dollar amount of business based on this market share, making it less likely that such an intermediary would risk its reputation. The greater the super-competitive profits over time, the less likely an intermediary will endanger these profits and its reputation through opportumistic behavior against its clients. ${ }^{41}$ Intermediary credibility through super-competitive profits, however, comes at the expense of reduced investor and issuer returns. In light of the potential problems posed by intermediaries, regulators could play a role in promoting the welfare of intermediary-level investors.

As with issuers, a self-tailored regulation system aimed at intermediaries could improve the level of investor protection. For example, under self-tailored regulation, intermediaries could bind themselves to particular screening procedures, conflict of interest prohibitions, mimmum capitalization requirements, and other devices at a lower cost than through contract or reputation. Intermediaries could also opt for public or private enforcement as well as criminal liability. By providing smaller intermediaries a cost-effective means of signaling their quality credibly to investors, self-tailored regulation would also increase competition among intermediaries.

40. See Choi, supra note 22 , at $943-45$.

41. For example, in the U.S. debt-rating market, two companies, Moody's and Standard \& Poor's, hold the vast majority of market share. See, e.g., John W. Milligan, How Moody's and S\&P Play the Bank Rating Game, U.S. BANKER, Aug. 1996, at 54. The large market share helps to bond Moody's and Standard \& Poor's in remaining truthful in their certification of debt; to the extent one of them falsely certifies a debt issue, for example, they run the risk of losing market share and the concomitant profits. 
Self-tailored regulation for intermediaries would complement a selftailored regime for issuers. Although intermediary-level investors lack information on particular issuers, intermediaries acting as agents for investors would pressure issuers to minimize the risk to investors. Where issuers possess the ability to institute desired investor protections through self-tailored regulation more cheaply than intermediaries, intermediaries would compensate issuers to do so. For example, some securities trade on fragmented markets where information on transaction prices and volume, as well as on offers to buy and sell securities, is not readily transmitted across markets. Because trading on fragmented markets reduces liquidity and thereby investor welfare, Ameritrade will direct Sarah only to issuers that apply self-tailored regulation to restrict trading of their securities to only certam markets. ${ }^{42}$ In turn, issuers gain to the extent they are able to sell their securities to a larger pool of investors through Ameritrade; as well, investors inay pay inore for securities recommended through a trusted advisor.

Self-tailored regulation also reduces the risk of regulatory capture, in which regulators cater to the interest of the regulated intermediaries. Regulators who later seek employment within the regulated industry or who are under the oversight of congressional subcommittees with which intermediaries have influence may experience regulatory capture. ${ }^{43}$ Even those regulators not prone to regulatory capture may suffer from regulatory tunnel vision. To the extent that intermediaries are repeat capital market players, they may possess greater capital market expertise than regulators. Financial institutions, for example, have involved themselves to a great extent in helping regulators determine what services are necessary for an underwriter to meet its "due diligence" obligation under the Securities Act. ${ }^{44}$ Thus, under the existing system, intermediaries may tend to pursue collective goals rather than the specific needs of their investors. By introducing competition, self-tailored regulation would encourage individual intermediaries to focus on the precise needs of their chentele.

In addition to self-tailored regulation, regulators may reduce the cost to investors of becoming informed on different intermediaries. Regulators, for example, may mamtain a list of intermediaries providing investor protection-related services; regulators may then publicize the list. This Article

42. See infra notes 131-32 and accompanying text (discussing the negative impact market fragmentation has on liquidity).

43. See Paul J. Quirk, Industry Influence in Federal Regulatory Agencies (1981); Cass R. Sunstein, Constitutionalism After the New Deal, 101 HARv. L. Rev. 421, 448 (1987); John Shepard Wiley, Jr., A Capture Theory of Antitrust Federalism, 99 HARv. L. Rev. 713 (1986).

44. See Reinier H. Kraakman, Gatekeepers: The Anatomy of a Third-Party Enforcement Strategy, 2 J.L. EcoN. \& ORG. 53, 83 (1986) ("Over the years, the securities bar and the underwriting community have honed the chief Section 11 investigation-the underwriter's due diligence investigation-into model verification procedures."). 
proposes no explicit registration criteria for intermediaries as exist in the present regime. What matters is the ability of investors to determine the type of service, the amount of risk, and the level of investor protections provided through an intermediary. Regulators, therefore, need not distinguish between investment advisors, broker-dealers, or exchanges. Instead, regulators should require intermediaries to provide information relating to each intermediary's investor protection regime..$^{45}$ Regulators may also maintain a record of past complaints against specific intermediaries to help investors determine the reputation of particular institutions. The Internet, in particular, will reduce investors' information costs by allowing them access to a centralized database of registered intermediaries. ${ }^{46}$ For example, the NASD, a private self-regulatory organization, has plans to place its Central Registration Depository on the Internet, allowing investors to gain access to past disciplinary history and other information for NASDregistered broker-dealers. ${ }^{47}$

Although intermediaries can be an efficient source of investor protections, they inay also be a source of additional risks for investors. Intermediaries may act unfaithfully in their screening for issuer quality. In addition, intermediaries may inake unwise investnent decisions for their clients, fail to execute transactions in a timely manner, or even einbezzle funds. Even well-intentioned but thinly capitalized intermediaries inay go bankrupt, leaving clients with only unsecured claims to their money. As with issuer fraud, however, rational investors with adequate information on the risks posed by intermediaries will adjust the amount they are willing to pay accordingly. Intermediaries then internalize the cost they impose on investors and will introduce value-maximizing contract and self-tailored regulatory protective measures. ${ }^{48}$

Investors also face the risk that a new intermediary inay be formed, listed with the SEC, and then used to defraud investors. For exanuple, consider Jack, an unscrupulous promoter. Jack forms Tech Brokers, Inc., publicizes the intermediary, and discloses that Tech Brokers einploys absolutely no investor protections. Through Tech Brokers, Jack proceeds to direct his investor-clients to the stocks of fly-by-night companies; in addition, Jack receives kickbacks from companies that he recommends.

45. Requiring the filing of provided investor protections also reduces the possibility of misunderstanding between investors and intermediaries as to the level and type of protections.

46. Already, investors may access the SEC's own web page to download recent EDGAR filings. See EDGAR Database (visited Oct. 31, 1999) <http://www.sec.gov/edgarhp.htm>.

47. See Ruth Simon and Aaron Lucchetti, Disciplinary Records of Stockbrokers Won't Be on Web This Spring After All, WALL Sr. J., Jan. 18, 1999, at B2 (describing the NASD's plan to put broker disciplinary records on the web and their decision to postpone temporarily the plan due to legal liability concerns).

48. For example, if a particular investor protection device costs an intermediary $\$ 1,000$ but raises the amount of additional revenue that an intermediary will receive from investors by $\$ 10,000$, the intermediary will put the protection device into place. 
Under this Article's proposal, intermediary-level investors would have no securities law recourse once they lost their money because Tech Brokers did not commit to any investor protections.

Nevertheless, this outcome is desirable to the extent intermediarylevel investors understand the risks of dealing with particular intermediaries. Those investors who choose intermediaries that fail to implement any investor protections receive a benefit: They pay less for intermediary services. For example, many investors have complained that $\mathrm{E}^{*} \mathrm{Trade}$, an Internet-based broker, is slow in executing trades, particularly during times of high inarket volume. ${ }^{49}$ Nevertheless, the investors are compensated by the relatively low $\$ 14.95$ commission they pay on trades through $\mathrm{E}^{*}$ Trade. ${ }^{50}$ When intermediary-level investors bear the burden of their choice, they will focus on the investor protections that different intermediaries provide. Ultimately, because investors will pay more for valued protections, the ability to choose from a range of intermediaries will result in improved intermediary-based services and investor protections.

\section{Aggregate-Level Investors}

An investor-regulation system could include other categories of informed investors in addition to issuer-and intermediary-level investors. For instance, many investors lack the resources and incentives to investigate the reputation and investor protections provided through either issuers or the general pool of intermediaries. Nevertheless, some of these investors may find it cost-effective to inform themselves on the reputation and provided investor protections of certain highly visible organizations (HVOs). HVOs might include exchanges, broker-dealers, mutual funds, and other nationally known professional organizations. For example, an investor may not know about the general reputation of a range of intermediaries but might have good information on a national broker-dealer such as Merrill Lynch.

To illustrate the flexibility of an investor-regulation system, this Article proposes to classify investors with the capacity to track highly visible organizations as "aggregate-level" investors. To implement a definition of HVOs, regulators face several possible choices. First, regulators may choose to make their own independent judgment. They may look to the inarket share or revenue of particular intermediaries as a proxy for the likelihood that aggregate-level investors will have adequate information about these entities. Such an approach has the advantage of providing an

49. See Susan Pulliam et al., Internet Traders Had It Tougher than the Shares, WaLl ST. J., Jan. 14, 1999, at C1.

50. See $E^{*}$ Trade (visited Oct. 31, 1999) <http://www.etrade.com>. Investors at Suretrade.com pay only $\$ 7.95$ per trade. See Suretrade.com-Welcome Visitors (visited Oct. 31, 1999) <http://www.suretrade.com>. 
expert assessment of which intermediaries and intermediary organizations truly are nationally known. On the other hand, active regulatory certification of HVOs has the disadvantage that regulators may become tempted to insert other more merit-based criteria in their selection of HVOs in addition to the level of market awareness aniong aggregate-level mvestors.

A second option is for regulators to let aggregate-level investors decide for themselves, as a group, the entities that may obtain HVO status. For example, regulators could poll aggregate-level investors about those intermediaries with which the investors are familiar. Although individual polling would not be a reliable indicator, those intermediaries obtaining a high number of responses would be likely candidates for HVO status. Under this approach, intermediaries may then have an incentive to advertise widely to investors to increase their name recognition. Nevertheless, this will increase investor knowledge about such intermediaries and provide for better investment decisions as a result. A third option would be to counbine these two approaches: Regulators could use polling data for aggregate-level investors as an initial screening device and then conduct independent assessment of intermediaries that pass this screen.

Given these approaches to defining a workable group of HVOs, two types of entities are likely to become qualified as HVOs: (1) organizations aggregating the interests of several intermediaries and (2) nationallyknown individual intermediaries seeking to provide protections to aggregate-level investors. ${ }^{51}$ Examples of market participants in the first group include the NASD, the New York Stock Exchange (NYSE), the American Stock Exchange (AMEX), as well as the regional exchanges. These entities all work to regulate broker-dealer intermediaries through their role as selfregulatory organizations under the Exchange Act. ${ }^{52}$ Other unofficial intermediary-organizing institutions also operate in the market and could be candidates for HVO status. ${ }^{53}$

51. Note that some issuers may also enjoy high visibility among investors. Because such companies will most likely trade on an efficient market, all investors trading in the securities of such a company are treated as issuer-level imvestors in this Article's proposal. See infra Part I.A.5.

52. In part, this is due to the regulatory requirements placed on self-regulatory orgamizations. Under the present regime, secnrities exchanges are treated as self-regulatory organizations. Section 6(b)(5) of the Exchange Act mandates that a securities exchange cannot be registered until the SEC determines that the exchange's rules act to "prevent fraudulent and manipulative acts and practices, to promote just and equitable principles of trade." Exchange Act $\$ 6(b), 15$ U.S.C. \$ 78f(b)(5) (1994).

53. For example, the Certified Financial Planner Board of Standards, Inc., a nonprofit private organization founded in 1985, works to certify financial planners, allowing certified planners to use the Board's "mark" of identification. See CFP Board: About Us (visited Oct. 31, 1999) <http://www.cfpboard.org/main_abtus.html>. The Certified Financial Planner Board defines a financial planner as someone who aids in "the process of determining how an individual can meet life goals through the proper management of financial resources." CFP Board: About Us (visited Nov. 7, 1999) <http://www.cfp-board.org/cert_main.html>. As with registered self-regulatory organizations, the Certified Financial Planner Board sets criteria for its membership and provides guidance to its members on how to transact business and ensure investor protection. For example, to obtain a license to use the 
The combined number of organizations aggregating the interests of intermediaries is far smaller than the total number of intermediaries. As a result, intermediary aggregating organizations tend to have a greater national presence. Moreover, investors need to learn only the general reputation of such organizations. To the extent these organizations are long-term players in the capital markets, their stake in maintaining a wellknown reputation in the capital markets is higher than most individual intermediaries. A private organization that regulates intermediaries will also have an incentive to advertise the level of protection they offer to investors to the extent investors increase their willingness to pay for the services of intermediaries connected with the organization..$^{54}$

In the second group of potential HVOs are certain individual intermediaries that may also enjoy high visibility among investors. For example, Charles Schwab and Merrill Lynch are national in scope and, as a result, are well known among inany investors otherwise lacking knowledge of individual companies or other securities market participants. Whether HVOs are determined through the independent judgment of regulators or through polling aggregate-level investors, both of these intermediaries would most likely be considered HVOs. Treating highly visible intermediaries separately allows more investors to make use of the intermediaries' securities expertise, to the benefit of all market participants. Because of their visibility and desire to maintain their national reputations, highly visible market participants will have strong incentives to cater to the interests of aggregate-level investors. Those HVOs that provide desired protections will increase both investor demand and the willingness of investors to pay for services. Moreover, by identifying HVOs, regulators would reduce the cost to investors of researching HVOs, thereby increasing the number of aggregate-level investors. Regulators could further reduce research costs by publicizing lists of official HVOs and their adopted investor protections, among other things.

This Article proposes requiring aggregate-level investors to associate with an HVO or HVO-sanctioned market participant for all of their securities transactions. Thus, issuers and intermediaries would first have to

Certified Financial Planner "mark," planners must successfully complete the CFP Board's certification examination, testing knowledge on various key aspects of financial planning. The CFP Board also requires a minimum amount of experience and continuing education as well as adherence to its Code of Ethics. See id.

However, the CFP Board would not be a likely candidate for HVO status. First, under the approach of polling aggregate-level investors, few investors would be likely to know about the CFP Board. Second, regulators attempting an independent determination of the likelihood of aggregate-level investor knowledge would probably consider the CFP Board too small an organization for HVO status.

54. For investors unable to distinguish between different individual intermediaries, no single intermediary will have an incentive to provide valued protections. HVOs enable intermediaries to solve this collective action problem, binding all member intermediaries to particular investor protections and then advertising this package of protections to the public. 
obtain the approval of an HVO before they deal with an aggregate-level investor. Aggregate-level investors would be barred from trading in the securities of issuers that did not have HVO approval, regardless of the trading forum. Thus, HVOs would be in a position to impose private regulatory constraints on other market participants.

Other recent proposals have advocated increased exchange-based regulation. ${ }^{55}$ Although the aggregate-level imvestor portion of this Article's proposal includes exchanges in its HVO category, the two regulatory proposals differ in two key respects. First, investor regulation contemplates additional HVOs other than exchanges. For example, to the extent aggregate-level investors have good knowledge on the risks and investor protections of a nationally-known broker, the broker would also be able to obtain HVO status under this Article's proposal. Aggregate-level investors associating with the HVO broker could then trade in any available HVO-approved investment in the market. This would generate greater competition among HVOs to the benefit of investors. Second, aggregatelevel investors would be required to go to an HVO for all securities transactions, whether primary-or secondary-market-related. As a result, HVOs would have leverage with other market participants seeking to deal with aggregate-level investors. Issuer-level and intermediary-level investors, on the other hand, are free to associate with market participants lacking any HVO connection. ${ }^{56}$

Importantly, no reason exists to force official HVO status on securities exchanges or other organizations. Rather, entities with a comparative advantage in developing and enforcing investor protections that apply to

55. See, e.g., Paul G. Mahoney, The Exchange as Regulator, 83 VA. L. REv. 1453, 1459 (1997) ("Self-interested stock exchange members will produce rules that investors want for the same reasons that self-interested bakers produce the kind of bread that consumers want."); see also A.C. Pritchard, Markets as Monitors: A Proposal to Replace Class Actions with Exchanges as Securities Fraud Enforcers, 85 VA. L. Rev. 925 (1999) (proposing that securities exchanges take on a greater role in enforcing securities fraud class actions).

One criticism of exchange-based regulation is that the broker-dealer membership of exchanges skews the incentives of exchanges away from investor protection and toward trade volume maximization. Often, protecting investors will result in greater trade volume leading to no conflict. Nevertheless, it is theoretically possible for broker-dealers secking to maximize volume to sacrifice investor welfare. For example, someone may engage in "wash sales" to create the illusion of interest in a particular security. This illusion may hurt investors in general but increase trade volume. See, e.g., Pritchard, supra, at 79-80 (noting that "[t]he key to understanding the failure of the NYSE to respond to [market manipulation] abuses is that manipulation was inevitably accompanied by imflated trading volume. As a result the NYSE membership benefited from the manipulations as long as speculators were willing to participate"). In contrast, where the membership structure of an HVO leads an HVO to provide less than desired investor protections, rational aggregate-level investors will shift business away from the HVO. Competing HVOs, therefore, will respond with a shift in ownership structure that minimizes conflicts with investor protection. These HVOs will then advertise their more investorfriendly ownership structure to aggregate-level investors to mcrease business.

56. Of course, issuer-level and intermediary-level investors may voluntarily seek out market participants that choose to associate with an HVO. This association, however, is by choice and not required under invcstor regulation. 
broad groups of intermediaries and issuers would actively seek to do so for their own financial gain. As a result, some present-day securities exchanges might choose to focus solely on providing trading services and to forego HVO status. Other exchanges which have developed regulatory expertise and experience as self-regulatory organizations might find providing HVO services profitable.

As with the issuer-and intermediary-level portions of the proposal, this Article would allow HVOs to access government-supplied self-tailored regulation. Implementing a self-tailored regime allows HVOs, in conjunction with their nember intermediary institutions and associated issuers, to design value-maximizing investor protections across all levels of market participants. For example, the NYSE, in its role as a self-regulatory organization, presently maintains an elaborate investigation and enforcement apparatus. ${ }^{57}$ Although the NYSE investigates a wide variety of activities ranging from insider trading and market manipulation on the exchange to broker-dealer churning of client funds, private regulators at the NYSE are unable to issue subpoenas to aid their investigations, ${ }^{58}$ impose criminal penalties,${ }^{59}$ or place sanctions on those without a direct connection with the exchange ${ }^{60}$ Under a self-tailored regulatory system, the NYSE would be able to grant itself subpoena power, provide for criminal penalties, and extend the reach of its enforceinent authority to nonmember parties who nevertheless use exchange facilities to engage in market manipulation.

\section{Unsophisticated Investors}

Some investors may lack either the rationality or the capacity to investigate and accurately value protections provided at even the aggregate level. These investors will not value investor protections, causing inarket participants to choose not to provide any protections. This Article refers to such investors as unsophisticated investors.

As with aggregate-level investors, this Article proposes to restrict unsophisticated investors to only HVO or HVO-sanctioned narket participants. In addition, in recognition of the precarious informational state in

57. See David P. Doherty et al., The Enforcement Role of the New York Stock Exchange, 85 Nw. UNIV. L. REV. 637, 638 (1991) (noting that the NYSE devotes over 25\% of its staff to its regulatory division). Well before the passage of the federal securities laws, exchanges provided private regulation of both broker-dealer members of the exchange and listed companies. See generally Stuart Banner, The Origin of the New York Stock Exchange, 1791-1860, 27 J. LEG. STuD. 113 (1998) (describing the NYSE's early regulatory role).

58. See Doherty, supra note 57, at 641 n.26 (noting that "[t]he only subpoena power the Exchange has is the limited power granted under state law to nonjudicial tribunals to issue subpoenas for their hearings").

59. Sanctions available to NYSE regulators include expulsion or suspension froin the exchange as well as fimes. See id. at 641.

60. See id. at 640 (noting that NYSE enforcement is limited to NYSE members, member organizations and their employees, and to allied members and approved persons). 
which unsophisticated investors find themselves, the proposal goes one step further and would limit unsophisticated investors to investments in only passive index mutual funds as determined and supplied through an HVO or HVO-sanctioned entity.$^{61}$ Due to the passive nature of index funds, informational asymmetries that may disadvantage unsophisticated investors in the securities markets are at a minimum. Through an index fund, unsophisticated investors need not make any choice; instead, they purchase either the entire market or a large subset of the market.

To the extent unsophisticated investors desire to diversify their overall investments to include securities, the availability of index funds meets this preference. HVOs would also have a strong incentive to ensure the capital strength and efficient operation of their associated passive index funds in order to maintain their reputation as high-quality HVOs among aggregatelevel investors. Moreover, an HVO-sponsored passive index fund would find it advantageous to deal with unsophisticated investors to the extent unsophisticated investors represent a large share of investment dollars.

The main disadvantage of this Article's unsophisticated investor proposal is that such investors would lose the ability to invest directly in individual stocks or in actively managed mutual funds. To the extent such investnients offer superior risk-adjusted returns, unsophisticated investors may do systematically worse than other investors. Nevertheless, empirical evidence indicates that most investors enjoy better financial performance through a passive index fund than through an actively managed fund or individual stock picking. ${ }^{2}$ In addition, as the next Section discusses, the present regime already discriminates against unsophisticated investors. The tiered regulatory regime proposed in this Article would nnake this discrimination less arbitrary and ensure that it occurs only when it is in the best interest of the unsophisticated investors.

Others may argue that unsophisticated investors should not even have access to passive index funds. For those truly unable to assess investment risks, the opportunity to invest even through an index may result in poor investment allocation decisions. ${ }^{63}$ For example, unsophisticated investors

61. Regulators might consider placing limits on what constitutes an index fund. For example, index funds could be required to passively track at least 100 or more different companies' securities. In addition, regulators could mandate some minimum level of diversification across different industries.

62. See Burton G. Malkiel, Indexes: Why the Critics Are Wrong, WALl Sr. J., May 24, 1999, at A30 ('In most years, a Standard \& Poor's 500 index fund has a rate of return about two percentage points better than the average manager's; for the 10 years ending in 1998, the index outperformed the average manager by 3.5 percentage points, and did better than more than nine out of 10 active managers.").

63. For example, putting all one's money into a bank deposit account will result in a high level of security but a low investment return. On the other hand, putting money into a passive stock index fund will result in a reduced level of security but a higher level of investment return on average. Many unsophisticated investors may not know how to balance risk versus return differences between even passive index funds versus nonsecurity alternatives. 
might not appreciate the implications of assigning a certain percentage of their assets to stock index funds compared to bank deposits and other forms of imvestment.

Three responses to this criticism are possible. First, unsophisticated investors could seek advice from HVOs or HVO-sanctioned intermediaries. For instance, HVO-sanctioned investment advisors could contract with unsophisticated investors to aid them in allocating their investments between passive mdex funds and nonsecurities instruments. ${ }^{64}$ Second, to the extent investors are so unsophisticated that HVO-provided advice nevertheless results im poor imvestment decisions, these investors already fare far worse under the current regime where they may invest in a variety of illiquid and little-known securities. Finally, nothing in the investor-regulation proposal prevents regulators from dividing unsophisticated investors into multiple categories, separating out those investors able to comprehend the importance of investment allocation decisions and those unable to do so.

\section{Investor Regulation and the Efficient Markets Hypothesis}

Up to this point, this Article has focused on the information in the hands of specific investors. Not all investors have full knowledge of the range of different issuers, their adopted investor protections, and the risk of fraud. To become informed, investors require both adequate informational resources and the expertise to interpret this information. Information, however, is costly; even when provided freely, most investors have only limited ability and desire to read and analyze all relevant investment information on different companies. Nevertheless, for broad classes of issuers, the presence of efficient markets makes the lack of investment knowledge on the part of any particular investor irrelevant. For imvestors in coinpanies trading on an efficient market, this Article provides a presumption of issuer-level status.

Commentators have articulated several versions of the efficient markets hypothesis: the strong version, the semistrong version, and the weak version. ${ }^{65}$ Each version has different implications for an investor-based

64. Indeed, many financial institutions already provide easy-to-use asset allocation computer advisors through the Internet. For an example, visit Fidelity's web page at Welcome to the Fidelity.com Home Page! (visited Sept. 1, 1999) <http://www.fidelity.com>.

65. See generally Eugene F. Fama, Efficient Capital Markets: A Review of Theory and Empirical Work, 25 J. FIN. 383 (1970) (providing a survey of theoretical implications of efficient markets and empirical tests of the efficient markets hypothesis). The semistrong version of the efficient capital markets hypothesis posits that the secondary market price of companies reflects all publicly-available information on the company. This Article uses the term "efficient market" to refer to a trading market that displays features of a semistrong efficient market. See Daniel R. Fischel, Efficient Capital Markets, the Crash, and the Fraud on the Market Theory, 74 CoRNELL L. REv. 907, 911 ("The empirical evidence to date (with some exceptions) appears to establish the validity of the weak and semi-strong versions but not the strong form of the efficient capital inarkets hypothesis."); see also Jeffrey $\mathrm{N}$. Gordon \& Lewis A. Kornhauser, Efficient Markets, Costly Information, and Securities Research, 60 
proposal. For example, under the semistrong version of the efficient markets hypothesis, the market price of securities that trade in liquid markets and are well-followed by mvestment analysts will reflect all publicly available information on the securities. As investors trade based on publicly available information, the signal sent to other investors through these trades will cause the price for the securities to adjust. ${ }^{66}$ So long as the market price reflects a company's investment risk, even unsophisticated investors are compensated ex ante. In an efficient market, the mcentive for issuers to protect investors is the same as if all investors had complete information on the risks surrounding any individual company.

For example, consider John, an unsophisticated investor. If IBM's stock trades on an efficient market, John's lack of specific knowledge on IBM-related public information does not matter. Rather, IBM's stock price will already incorporate all public information. Where IBM adopts a valuable investor protection device that raises investor valuation of the coinpany by $\$ 5$ per share, Widget's stock price will increase by $\$ 5$. John, as a result, only must look to the stock price in determining whether to purchase IBM shares.

Many coinpanies fail to trade in an efficient market. ${ }^{67}$ To the extent this Article advocates regulatory freedom for issuer-level investors, regulators may wish to err on the side of caution im defining which companies do trade in an efficient market. For example, regulators could provide investors the presumption of issuer-level informed status only for companies followed by a significant number of investment analysts and with a relatively large public float and shareholder base. ${ }^{68}$ However, this limited

N.Y.U. L. REv. 761, 834-41 (1985) (reporting on studies that support the semistrong version of the efficient market hypothesis); Jonathan R. Macey, State Anti-Takeover Legislation and the National Economy, 1988 WIS. L. REV. 467, 471 (1988) (noting the "overwhelming evidence" supporting the semistrong form of the efficient capital markets hypothesis).

66. See Ronald J. Gilson and Reinier H. Kraakman, The Mechanisms of Market Efficiency, 70 VA. L. REv. 549 (1984).

67. Several commentators have argued that markets are not efficient because of investor irrationalities and cognitive limitations in processing information. See Donald C. Langevoort, Theories, Assumptions, and Securities Regulation: Market Efficiency Revisited, 140 U. PA. L. REv. 851, 853-54 (1992); Lynn A. Stout, Are Stock Markets Costly Casinos? Disagreement, Market Failure, and Securities Regulation, 81 VA. L. REv. 611, 648-50 (1995). Still others argue that markets are not efficient due to the presence of "noise traders" who trade not based on information but rather due to liquidity needs. See J. Bradford De Long et al., Noise Trader Risk in Financial Markets, 98 J. Pol. ECON. 703, 713, 717 (1990).

68. The SEC defines "public float" to equal the aggregate market value of the issuer's outstanding voting and nonvoting common equity held by nonaffiliates of the issuer. See 17 C.F.R. $\$$ 228.10(a)(1) (1999). The current securities laws partially recognize the validity of the efficient markets hypothesis through the tiered registration system of the Securities Act. Companies seeking to sell securities through a public offerimg typically register using Forms S-1, S-2, or S-3. See Securities Act Forms S-1, S-2, and S-3, 17 C.F.R. \& 239.11-13 (1999). The three registration forms correspond to the likelihood that the company is well followed and therefore trades in an efficient market. But see Palmiter, supra note 17, at 40 (noting that "[a]t the time [the SEC] adopted integrated disclosure, the SEC calculated that approximately thirty percent (about 3,000 ) of all publicly-filing companies would 
definition may leave medium-and smaller-sized companies with reduced access to the capital markets. Nevertheless, under this Article's proposal, inefficient market companies may still raise capital fronı issuer-level informed mvestors, ${ }^{69}$ as well as fronı other investors associated with intermediaries under the appropriate nivestor-regulation regime. ${ }^{70}$

\section{Comparison to the Present Regime}

At first glance, this Article's restrictions on the ability of certain investors to deal directly with different securities market participants may seen paternalistic. However, the investor-regulation proposal would actually provide nuost investors with greater investment choice. By focusing directly on the goal of investor protection, a tiered system of regulation would allow those investors able to assess the market to determine for themselves their desired protections. This Article's proposal would subject the different mechanisnis of investor protection to market discipline, allowing investors greater choice. One size does not fit all in investor protections: For example, issuer-level investors nuight desire a far lower degree of protection than would aggregate-level investors. At the same time, the regime would protect those investors less able to fend for themselves. $^{71}$

A comparison with the present securities regulatory framework demonstrates the value of this Article's proposal. In particular, an examination of the following three areas of existing regulation highlights the benefits of an investor-focused regime: registration requirements for public offerings, restrictions on private placemeuts, and special provisions governing offerings by sniall businesses. First, issuers conducting a public offering must file a registration statement with the SEC. ${ }^{72}$ Because of this requirement,

qualify for the S-3 exemption from full-prospectus preparation, yet an SEC Advisory Committee had concluded that only 1,000 companies were actually closely followed by securities analysts").

As an alternative means to implement the issuer-level elassification for efficient market companics, regulators could start with Form S-1-classified companies and, erring on the side of caution, provide additional shareholder, public float, and investment analyst following requirements. In its recent Aircraft Carrier proposal, the SEC argued that companies meeting minimum public float and average daily trading volume requirements most likely trade in an efficient market. See The Regulation of Securities Offerings, Securities Act Release No. 33-7606A, 68 SEC Docket (CCH) 1425, at 1460 (Nov. 13, 1998) [hereinafter Aircraft Carrier Release].

69. As described above, issuer-level investors include those invcstors with actual information on the range of possible issuers, the investment risks they pose, and the available investor protection devices irrespective of the presence of an efficient market.

70. For example, an mefficient market company could deal directly with an internnediary-level investor associated with an appropriate securities market intermediary. See supra Part I.A.2 (describing this Article's investor regulation regime for intermediary-level investors).

71. Some commentators have recognized that the present securities laws have alrcady moved far toward providing choice in the level of regulation which companies face. See Palmiter, supra note 17, at 29-86. Nevertheless, regulators should maintain a direct focus on the types of investors in the market in adjusting levels of regulation.

72. See infra Part II.A (discussing the public offering process). 
investors seeking to purchase securities in a public offering from companies that eschew registration statements (thereby saving the direct costs of drafting the document and the indirect costs of potential antifraud hability) are generally unable to do so in the United States. ${ }^{73}$

On the one hand, the public offering requirement blocks otherwise sophisticated investors from purchasing and freely trading securities of issuers in which they would have good information even if the issuer chooses not to conduct a public offering. On the other hand, once issuers complete the public offering process, they may sell securities to any investor in the marketplace regardless of the investor's sophistication. ${ }^{74}$ However, segments of unsophisticated investors nnay lack the necessary expertise to assess the value of a particular company's securities even after a public offering. The mere fact that a coinpany files a registration statement with the SEC is no guarantee that an unsophisticated investor will be able to decipher and understand the filed information. This is particularly true of conipanies that fail to trade on an efficient market, ${ }^{75}$ requiring investors to make their own assessment of different companies' valuations. Through its direct focus on investors, investor regulation would allow investors with the capability to assess issuer-level risks for themselves to purchase the securities of any issuer. Investor regulation would then channel investors lacking such capabilities to intermediaries and investnent opportunities appropriate to the investors' ability to assess risks.

Second, the present regime does provide limited recognition for differences among investors through private placements. Section 4(a)(2) of the Securities Act, for example, provides an exemption froin the offering process nnder Section 5 to the extent an offering does not involve any "public offermg." The Supreme Court has held offerimgs aimed at investors able to fend for theinselves as meeting the requirement in Section 4(a)(2) that the offering not involve any public offering. ${ }^{77}$ Subsequent

73. Of course, issuers may seek to deal with only more sophisticated segments of investors through private placements. However, private placements result in restricted securities, imposing illiquidity on such securities. Qualified Institutional Buyers (QIBs) may then seek to purchase and resell such securities among themselves under Rule 144A of the Securities Act. See Seeurities Act Rule 144A, 17 C.F.R. $\$ 230.144$ A (1999). Nevertheless, many investors aside from QIBs may have the ability, either alone or with an intermediary, to assess the value of such securities but are unable to do so under the present regime. See infra text accompanying notes 76-82 (comparing investor regulation regime with private placements).

74. Section 4(1) of the Securities Act exempts any transaction not involving an issuer, underwriter, or dealer from the registration requirements of Section 5 of the Securities Act, providing for free secondary market trading for most securities already through the public offering process. Importantly, Sectiou 4(1) makes no distinctions between different types of investors. See Securities Act $\S 4(1), 15$ U.S.C. $\& 77 \mathrm{~d}(1)$ (1994).

75. See supra note 67 (citing antiefficient market hypothesis proponents).

76. See Securities Act $\S 4(a)(2), 15$ U.S.C. $\$ 77 \mathrm{~d}(\mathrm{a})(2)$.

77. See SEC v. Ralston Purina Co., 346 U.S. 119, 125 (1953) ("An offering to those who are shown to be able to fend for themselves is a transaction "not imvolving any public offering."). 
circuit court opinions have held that Section 4(a)(2) requires that investors either have access to relevant investment information or receive the information directly; as well, sophistication is important in determining the investors' ability to use the information. ${ }^{78}$

Issuers may also avoid regulations governing public offerings and sell securities without any niandated disclosure or restrictions on the numbers of investors through a private placenient under Rule 505 or 506 of the Securities Act so long as all investors are "accredited." Accredited investors are defined to include certain financial institutions and, in the case of individuals, investors with an annual inconie over $\$ 200,000$ for each of the two nost recent years or a net worth over $\$ 1$ million. ${ }^{80}$ Similarly, Rule 144A of the Securities Act provides that "qualified institutional buyers" (QIBs) may purchase restricted securities so long as certain basic information on the securities exists in the market and the securities are not fungible with securities trading in an established exchange, among other requirenients. ${ }^{81}$ Rule 144A, in turn, defines QIBs to include mostly large financial institutions with over $\$ 100$ million in invested assets. ${ }^{82}$ Furthermore, in applying various provisions of the securities laws, courts also take investor sophistication into account. ${ }^{83}$ For example, courts use investor sophistication in determining whether a broker has engaged in churning ${ }^{84}$ or has sold unsuitable securities to a particular investor..$^{85}$

However, the limited recognition of differences among investors in private placenients falls far short of this Article's proposal. Even where sophistication is recognized, investors are unable to free themselves completely of mandatory regulations. For instance, parties selling restricted securities to QIBs pursuant to Rule 144A still face potential Rule 10b-5 antifraud liability for the transaction. ${ }^{86}$ Moreover, in areas where investor sophistication is recognized, recognition is sporadic and uncertain. For example, although some courts will look at investor sophistication in

78. See, e.g., James D. Cox et al., Securities Regulation: Cases \& Materials 378-90 (2d ed. 1997) (describing a Fifth Circuit line of cases expanding on Ralston Purina).

79. See Securities Act Rule 506, 17 C.F.R. \$ 230.506 (1999). For investors that fail to meet the accredited standard, Rule 506 imposes a limit of not more than 35 purchasers. Moreover, the purchasers must have enough sophistication to judge the merits and risks of the offering, either on their own or through a purchaser representative. See Securities Act Rule 506(a), 17 C.F.R. $\$ 230.506$ (a).

80. See Securities Act Rule 501(a)(5-6), 17 C.F.R. § 230.501(a)(5-6).

81. See Securities Act Rule 144A, 17 C.F.R. § 230.144A. Since its introduction in 1990, offerings making use of Rule 144A have expanded greatly. In 1997, the SEC reported that Rule 144A comprised $17 \%$ of the total dollars sold through all offerings. See Aircraft Carrier Release, supra note 68 , at 1433 .

82. See Securities Act Rule 144A, 17 C.F.R. § 230.144A.

83. See, e.g., Fletcher, supra note 14, at 1083-88.

84. See id. at 1103 (noting that "[s]ophisticated investors' churning claims almost always fail").

85. See $i d$. at 1108 (noting that "[i]n cases involving sophisticated customers, courts are more likely to hold that no fiduciary relationship exists at all or that a broker's fiduciary duty is easily met").

86. See Securities Act Rule 144A Preliminary Note, 17 C.F.R. § 230.144A. 
determining reasonable reliance under Rule $10 \mathrm{~b}-5$, other courts refuse to do so. ${ }^{87}$ The private placement rules also fail to fully protect the truly unsophisticated. After a one-year holding period, initial investors in a private placement may use Rule 144 to sell securities to the general public without regard to their sophistication. ${ }^{88}$ As with public offerings, investor regulation improves on private placements through direct recognition of the differences among investors. Under investor regulation, for example, unsophisticated investors would be unable to purchase securities other than through passive index funds regardless of the passage of any holding period. ${ }^{89}$

Third, the present securities regime provides a number of specialized provisions geared toward small businesses. The regime often equates sinall businesses with unsophisticated investors and imposes special limitations. One such example is the Securities Enforcement and Penny Stock Reform Act of 1990, which Congress enacted out of concern about fraud in penny stocks. Penny stocks generally include stocks that trade on the Over-theCounter (OTC) inarket as opposed to NASDAQ or one of the securities exchanges, and whose trading price is relatively low, below $\$ 5$ per share. ${ }^{90}$ Because trading in OTC securities is usually conducted by brokers and dealers working for sinaller, less well-known brokerage intermediaries, greater fears of investor abuse exist, including high-pressure "cold-call" sales tactics and inarket manipulation. ${ }^{91}$ Among other things, the Penny Stock Reform Act requires the SEC to impose more coniprehensive disclosure for penny stocks. ${ }^{92}$

To the extent companies issuing penny stocks are predominantly sinaller issuers, the penny stock regulations weigh disproportionately on small businesses. Despite the concern for unsophisticated investors, the conclusion does not follow that regulators should also burden sophisticated investors with the cost of penny stock protections. Investors with information-either direct information in the case of issuer-level investors or indirect information through intermediaries in the case of intermediary and

87. See, e.g., Fletcher, supra note 14, at 1089 (citing In re Olympia Brewing Co. Sec. Litig., [1985-1986 Transfer Binder] Fed. Sec. L. Rep. (CCH) I 92,461, at 92,819 (N.D. Ill. Nov. 13, 1985)).

88. See Securities Act Rule 144, 17 C.F.R. $\$ 230.144$.

89. In addition, as discussed in Part I.A.5, for companies whose securities trade in an efficient market, all investors-even the unsophisticated-are treated as issuer-level. Therefore, unsophisticated investors can invest directly in such companies' securities.

90. Penny stocks are defined as any equity security unless an exclusion applies. See Excliange Act $\S 3(a)(51), 15$ U.S.C. $\$ 78 c(a)(51)$ (1994). Securities traded on a national securities exchange or NASDAQ are excluded. See id. The SEC also excludes securities that trade above a price of five dollars or more. See Exchange Act Rule 3a51-1(d), 17 C.F.R. \$ 240.3a51-1(d) (1998).

91. See Carolyn E. Lampe, Comment, The Penny Stock Reform Act of 1990: A Costly Solution to a Serious Problem, 13 Geo. Mason U. L. Rev. 779, 780-84 (1991).

92. See Exchange Act $\S 15(\mathrm{~g}), 15$ U.S.C. $\S 78 \mathrm{o}(\mathrm{g})$. Increased restrictions on "blank check" registrations involving issuers with open-ended business plans were also imposed. See Securities Act $\S$ 7, 15 U.S.C. $\$ 77 \mathrm{~g}$. 
aggregate-level investors-can price the presence of any investor protections, giving even penny stock companies an incentive to adopt voluntarily value-maximizing protections.

Conversely, several sections of the Securities Act favor small businesses. Small businesses, for example, may register securities for public offerings using reduced information disclosure forms. ${ }^{93}$ In addition, through Regulation A and Rule 504 of Regulation D, small businesses may issue a limited dollar amount of unrestricted securities through a widespread offering without ineeting the extensive disclosure and gun-jumping rules required under Section 5 of the Securities Act.94 Allowing truly unsophisticated imvestors to purchase securities of small speculative businesses, however, may lead to both mistake and fraud. Investor regulation provides an alternative to the varied treatment of small businesses under the present regime. In particular, investor protection would allow issuer-level investors to transact freely with small business issuers without the added cost of forced regulatory safeguards, while channeling less sophisticated investors to interinediaries able to negotiate for desired protections.

Investor regulation must be judged against the alternative of mandatory regulation. In particular, even well-intentioned regulators inay lack the industry knowledge and expertise to provide socially beneficial regulations. Mistakes also occur, resulting in inefficient and costly regulations. If existing regulations turn out to be ineffective or inefficient, regulators face large costs in determiming when and how to change the regulations. Moreover, there are general probleins with government regulation that might apply to securities regulators. For example, regulators may experience regulatory capture. ${ }^{95}$ Such regulators may impose greater and more complex regulations without regard to alternative inechanisms that inay exist in the market to protect imvestors. Other regulators inay seek to impose expanded levels of regulation even when unnecessary to expand the power and responsibility of their particular agency. ${ }^{96}$

Regulators might also possess an incentive to retard the introduction of new sorts of financial services, such as Internet-based trading, ${ }^{97}$ to reduce the chance that Congress inay intervene. This incentive arises from an asymmetry, as new services that are blocked will produce "invisible" victims who inay have potentially benefited from the service; conversely,

93. See Securities Act Form SB-1, SB-2, 17 C.F.R. \& 239.9-239.10 (1999).

94. See generally Stephen J. Choi, Gatekeepers and the Internet: Rethinking the Regulation of Small Business Capital Formation, 2 J. SMALL \& EMERGING BUS. LAW 27, 31-35 (1998) (describing the accommodations made in the Securities Act for small business issuers). Both Rule 504 and Regulation A apply only to non-Exchange Act reporting companies. See Securities Act Rule 504(a)(1), 17 C.F.R. \$ 230.504(a)(1); Securities Act Rule 251(a)(2), 17 C.F.R. § 230.251(a)(2).

95. See supra note 43 and accompanying text.

96. See William A. Niskanen, JR., BurEaucracy aNd Representative Government 38 (1971).

97. See infra Part II.B (describing the SEC's new rules governing alternative trading systems). 
new services that are not blocked will result in an actual victim of fraud if, for example, the service proves unreliable. To the extent actual victims petition Congress and call for reform, the agency runs a greater risk of political confrontation when it sanctions new services. ${ }^{98}$ As a result, regulators have incentives to entrench the regulatory status quo. For fastchanging industries, such as the securities industry, this bias toward the status quo results in increasingly outdated regulations.

Finally, investor regulation provides a systein easily adaptable to the growing international capital markets. Focusing on investor sophistication provides regulators the ability to allow informed investors access to the securities of foreign companies while restricting the choice of other investors. For example, those investors able to assess the risks of investing with individual issuers-issuer-level investors-will price the protective value of all alternative investor protections accordingly. Whether the alternative protection is based in contract, through selftailored regulation within the Umited States, or through a foreign-based regulatory body, issuer-level investors will reward issuers by selecting value-1naximizing protections. Therefore, under investor regulation, issuerlevel investors should face no barriers to international investments. ${ }^{99}$ Similarly, intermediary-level investors nay trade internationally without restriction so long as they associate with appropriate intermediaries. On the other hand, unsophisticated investors should face stringent restrictions against international investments, allowing them to obtain access only to HVO-sponsored international passive index funds.

Of course, alternative investor classifications are possible. This Article proposes only a starting point for the general proposition that investor welfare is increased when investors who are capable of judging the value of regulatory protections have access to a wider spectrum of inarket participants. The following table summarizes the proposed regime:

98. See Hugo Hopenhayn \& Susanne Lohmann, Fire-Alarm Signals and the Political Oversight of Regulatory Agencies, 12 J.L. ECON. \& ORG. 196, 204 (1996) (presenting an economic model demonstrating conditions when regulatory agencies may have a bias toward "prohibiting the activity in order to reduce the likelihood that the principal receives unfavorable information"); Steven M.H. Wallman, Competition, Innovation, and Regulation in the Securities Markets, 53 Bus. LAw. 341,346 (1998) ("Frequently, criticism is leveled at regulators' concrete failure to protect someone who is hurt, rather than for precluding something new or experimental that might-alihough no one is sure--have led to a better world.").

99. Indeed, issuers should have complete freedom under self-tailored regulation to adopt the regulatory protections of a foreigu regime. See, e.g., Stephen J. Choi \& Andrew T. Guzmán, Portable Reciprocity: Rethinking the International Reach of Securities Regulation, 71 S. CAL. L. REv. 903 (1998); see also Roberta Romano, Empowering Investors: A Market Approach to Securities Regulation, 107 YALE L.J. 2359 (1998) (providing an argument for issuer choice among competitive state-based securities regulatory regimes). 
Table I: Permissible Associations Under Investor RegulationSecurities Market Participants

\begin{tabular}{llll}
\hline TYPES OF INVESTORS & IsSUERS & INTERMEDIARIES & HVOs \\
\hline $\begin{array}{l}\text { Issuer-Level } \\
\text { Investors } \\
\text { (including investors in } \\
\text { efficient inarkets) }\end{array}$ & All issuers & All intermediaries & All HVOs \\
$\begin{array}{l}\text { Intermediary-Level } \\
\text { Investors }\end{array}$ & $\begin{array}{l}\text { Only issuers } \\
\text { associated with } \\
\text { intermediaries or } \\
\text { HVOs }\end{array}$ & All intermediaries & All HVOs \\
& $\begin{array}{l}\text { Only issuers } \\
\text { associated with } \\
\text { HVOs }\end{array}$ & $\begin{array}{l}\text { Only intermediaries } \\
\text { associated with } \\
\text { HVOS }\end{array}$ & All HVOs \\
$\begin{array}{l}\text { Investors } \\
\text { Not allowed }\end{array}$ & $\begin{array}{l}\text { Only intermediaries } \\
\text { associated with } \\
\text { Insophisticated }\end{array}$ & $\begin{array}{l}\text { All HVOs (passive } \\
\text { (passive index } \\
\text { funds only) }\end{array}$ \\
\hline
\end{tabular}

\section{B. Investor Classification}

To implement this Article's proposal, regulators must differentiate among investors. This Section proposes a licensing system whereby investors, prior to engaging in any securities transaction, obtain a license from the SEC as issuer-, intermediary-, or aggregate-level investors. Investors who fail to receive a license are treated as presumptively unsophisticated. This Section discusses possible forms of licensing including: (1) mandatory licensing, (2) voluntary licensing, and (3) hybrid arrangements.

\section{Mandatory Licensing}

Where the present regime does recognize differences among investors, regulators often employ wealth- and income-based proxies for sophistication. For example, Regulation D of the Securities Act employs the notion of "accredited investors," defined in part by net worth and income. ${ }^{100}$ Similarly, Rule 144A's qualified institutional buyer concept depends on institutional status and the amount of net assets. ${ }^{101}$ These proxies, however, are both under- and overinclusive in their reach. The

100. See supra text accompanying note 80 .

101. See supra text accompanying notes 81-82. 
definition of an accredited investor, for example, may treat otherwise financially sophisticated investors as nonaccredited, while treating financial neophytes as accredited. ${ }^{102}$

In response to the inadequacy of wealth-based proxies, commentators have listed alternative criteria to discern among different levels of imvestor sophistication..$^{103}$ Regulators, for example, nay look to education, years of investment experience, and the types of trades which an investor transacts, among other factors. ${ }^{104}$ None of these criteria, however, perfectly separates investors. For example, even investors with extensive investment experience may be unsophisticated. ${ }^{105}$ Conversely, investors who fail to meet any objective criteria of sophistication inay nevertheless possess good fmancial expertise and perform well in the inarket.

Despite the problems with objective screening niechanisms, nrandatory licensing of investors could improve such inechanisms by focusing directly on the information investors possess on securities inarket participants. What inatters is not general investor sophistication, but rather investors' ability to recogmize and properly assess alternative sources of investor protection. Therefore, instead of utilizing wealth or trading experience, an investor classification system should target investor knowledge of different market participants. In particular, regulators should test investor knowledge of the function of different market participants, the risks they pose, and available investor protections. For example, regulators might require an investor applying for an issuer-level license to demonstrate detailed knowledge of different issuers in the market, the business of these issuers, and available investor protections. Similarly, for an intermediary-level license, regulators might require an investor to display familiarity with the role of different types of intermediaries and possible investor protection devices that intermediaries offer.

Regulators and private parties could also use the licensing process to educate investors. Even without licensing, regulators could publicize information on market participants, reducing investors' research costs. ${ }^{106}$ Nevertheless, licensing provides regulators a focal point to inform

102. See, e.g., Howard M. Friedman, On Being Rich, Accredited, and Undiversified: The Lacunae in Contemporary Securities Regulation, 47 OKLA. L. REV. 291 (1994) (arguing that even accredited investors may be unsophisticated and require imvestor protections).

103. See, e.g., Fletcher, supra note 14, at 1149 (providing a hist of criteria related to financial and business acumen, individual characteristics of sophistication, and investment-specific behavior).

104. See id. (noting that none of the criteria are dispositive but vary case to case).

105. For example, consider a hapless unsophisticated investor who trades continually over a period of several years without bothering to learn about any aspect of the securities markets, thereby losing alınost all of her money. The investor will have "experience" with the markets but will nevertheless trade at the same knowledge level as other unsophisticated imvestors.

106. See supra text accompanying notes $45-47$ (proposing that regulators may aggregate and publicize information on intermediaries to reduce the cost to intermediary-level investors). 
investors of their options for private market protections as well as the reputations of different market participants.

Other government agencies already employ substantive licensing exams. To operate an amateur radio, for example, individuals must pass a Federal Commumications Commission licensing exam. ${ }^{107}$ To pilot a plane, mdividuals must pass a Federal Aviation Administration licensing exam. ${ }^{108}$ To assist the investor licensing process, the SEC could publish information on what level of knowledge is expected at each different license level. Similarly, private providers of both test preparation materials and courses might enter the market, helping to educate investors. Not only would a inandatory licensing regime filter out unsophisticated investors, but the testing requirenient itself might increase the average level of investmentrelated knowledge in the market. In addition, mandatory licensing would provide investors an incentive to educate theinselves about the risks facing them and possible protective devices. In order to expand their ability to invest, investors would need to obtain higher licensing levels corresponding to greater knowledge of different securities market participants.

Mandatory licensmg would also furnish the market with infornuation on the range of different investors in the market. For example, the SEC could keep the inarket regularly informed on the proportion of different classes of investors. Information on the numbers of issuer-, interniediary-, and aggregate-level investors would assist market participants in determining where they inay most profitably develop investor safeguards. For example, in a market where most investors are issuer-level, intermediaries will expend fewer resources in developing their screening capabilities for fraud. On the other hand, where many investors are intermediary-level, internediaries will have more incentive to expend resources in developing investor protection programs.

Finally, the presence of easily-tracked licenses for investors would provide the SEC a low-cost means of ensuring coinpliance with investor regulation. Under this licensing proposal, the SEC could assign a unique license number to registered investors. License numbers from random audits of brokers, securities exchanges, and other interniediaries could then be coinpared agaimst the SEC's database to ensure that inarket professionals comply with the tiered nivestor-regulation regime.

As proposed, mandatory licensing suffers from inevitable flaws. First, the actual process of licensing investors introduces a layer of complexity to the investment decision. The SEC would have to design tests and

107. The American Radio Relay League provides information on obtaining an FCC license at ARRL Web: ARRL Information and Services (visited Oct. 31, 1999) <http://www.arrl.org/iands.html>. See also Federal Communications Commission (FCC) Homepage (visited Sept. 1, 1999) $<$ http://www.fcc.gov>.

108. See Aviation Professionals-Federal Aviation Administration's Website (visited Oct. 31, 1999) <http://www.faa.gov/aviation.htm>. 
educational materials. ${ }^{109}$ Investors would have to expend resources learning the test materials and taking the tests. While results are computed, investors would also have to forego making securities market transactions until they receive a valid license, resulting in possible opportunity costs. Despite these difficulties, the complexity involved is far less than that in the present regime, which imposes separate regulatory requirements on different market participants. In contrast, a mandatory licensing regime would regulate only investors. Once licensed, investors would then be able to interact with appropriate market participants freely. Delays would also be reduced in an investor-regulation regime. Licensed investors would form a pool of readily accessible capital for issuers to draw from at a moment's notice, without having to comply with mandatory filing and other regulatory requirements.

Second, as with other forms of mandatory objective licensing, errors are possible. Some well-informed investors might fail to receive a higher level of licensing despite their qualifications, leading to an underinclusive licensing regime. Conversely, some less-informed investors might imistakenly receive licensing at a higher level than their abilities warrant, resulting in overimclusive licensing. Relative to the present regime's use of net worth as a proxy for experience, however, the focus on investor knowledge and education would reduce investor screening errors. In addition, the present regime's failure to take consistently into account the needs of different types of investors through its public offering, private placement, and small bnsiness regulatory framework ${ }^{110}$ results in a far greater rednction in investor welfare than do these potential flaws of investor regulation.

\section{Voluntary Licensing}

This Article argues that rational investors who understand their own information capacity will self-select into appropriate regulatory categories, thereby creating an alternative to inandatory licensing. For instance, an investor might not have good issuer-, intermediary-, or even aggregatelevel information; nevertheless, this investor will realize her lack of information and will therefore choose a regime designed for her particular level of market information. To select a category with more sophisticated mvestors ensures that an investor will suffer from an informational disadvantage in her transactions. Put another way, the investor will fail to receive investor protections she would find valuable because no other investor in her selected group desires these protections.

109. Other federal agencies already employ written licensing tests effectively. Both the FCC and the FAA use written tests for their licensing regimes. See supra notes 107-08.

110. See supra Part I.A.5 (comparing investor regulation to the present securities regulatory regime). 
For example, consider Andrew, an unsophisticated investor. Under a voluntary licensing scheme, if Andrew opts into the category of issuerlevel investors, he will purchase securities of issuers that focus their efforts and investor protections on issuer-level investors. Consequently, no investor protections will exist to protect the unsophisticated in the issuer-level market segment; issuer-level investors will refuse to pay for these protections. Andrew will therefore be at a greater risk of fraud among other risks and will systematically do worse than more sophisticated investors in the market. To the extent Andrew is rational and understands his own capabilities, he will therefore choose not to license himself as an issuer-level investor. ${ }^{111}$

On the other hand, investors who select a category designed for those with less information would be required to bear greater regulatory costs than necessary. For example, consider Jesse, an issuer-level investor. If Jesse chooses to license himself as an aggregate-level investor, he will be restricted to transacting only with HVOs that supply investor protections geared toward aggregate-level investors. Even though Jesse does not value these protections, he will nevertheless have to pay for them indirectly through higher service fees and commissions to the HVOs and associated intermediaries. Jesse will have an incentive not to select into a less informed group of investors.

Rational investors, therefore, would have an incentive to opt into the regime best suited to their information needs. Choosing the appropriate regime would not depend on an investor's level of investment experience, but rather on that investor's understanding of her level of expertise. Investors could choose for themselves whether they fall into the issuer-, intermediary-, or aggregate-level categories. Investors who do not register would automatically be considered unsophisticated. ${ }^{12}$

Compared with mandatory licensing, voluntary licensing has the benefit of reduced costs. The SEC, for example, would not need to design or administer licensing exams. Similarly, investors would not need to spend time or effort studying for the licensing exams, nor would they

111. One potential criticism is that even an unsophisticated investor may voluntarily select issuerlevel status to keep her options open. An issuer-level investor, for example, can always later restrict herself to investing only through HVOs. Investors who choose unsophisticated status, on the other hand, are always limited only to HVOs. Nevertheless two responses are possible. First, an investor's selection of a particular licensing level affects the type of market participants that may approach the investor. Where an aggregate-level investor chooses issuer-level status, she must then expend rcsources distinguishing between a wide variety of different market participants and the protections they provide. On the other hand, an aggregate-level investor choosing aggregate-level status can rely on legal penalties to restrict the class of market participants that approach her to HVOs, reducing her research costs. Second, as discussed in the next Section, regulators could impose miuimum criteria for different license levels to reduce the problem of miscategorization of investors.

112. Investors dealing in securities of efficient market companies as well would be automatically considered issuer-level, informed with respect to transactions in these securities. See supra Part I.A.S. 
experience licensing delay. Finally, where investors self-select accurately, there is less risk of over- or underinclusive licensing compared to a mandatory regime.

This Article proposes requiring investors to make their voluntary licensing choice prior to any securities transactions, as is the case with inandatory licensing. In contrast, one could argue that for rational investors with knowledge of their own investment abilities, no regulation is necessary. Investors who realize their own limitations will choose the best sources of protection in the marketplace to maximize their welfare. Nevertheless, there are several reasons investors imight find additional benefits from a requirement to obtain a license prior to any specific securities transactions.

First, ex ante licensing would protect investors against pressure from opportunistic promoters pushing specific investments. Investors will make better decisions about their own expertise when freed from this sort of pressure. While the circumstances around any particular decision should make no difference for completely rational investors, prior registration would serve a cautioming function for others. Investors may suffer from overoptimism with regard to their abilities and to the potential investment return in any particular transaction. Requiring preregistration would provide investors the opportunity to assess their own ability in a more neutral setting. ${ }^{113}$

Second, ex ante licensing would provide regulators information to ensure that the voluntary investor classification system is functioming. Without a licensing system, regulators would lack a mechanism for monitoring instances in which less sophisticated investors mistakenly choose to license theinselves as issuer-level investors and deal directly with issuers. Through licensing, regulators would be able to determine whether investors actually self-select into appropriate categories. For exainple, regulators could conduct surveys of particular categories of licensees to assess how often investors in each category are defrauded.

In some areas of the present regime, imvestors already receive de facto licensing prior to the investanent decision. For example, issuers may not sell securities pursuant to a private placement under Rules 505 or 506 of the Securities Act through a "general solicitation"; ;14 instead, issuers may

113. The SEC's recent move to allow certain companies to "test the waters" prior to making an offering under Regulation A of the Securities Act embodies a similar assumption: So long as investors have a "cooling off" period, the danger of mistake and bad business decisions decreases. Rule 254 of the Securities Act sets up the cooling off period, requiring that sales not commence until 20 calendar days after the last pubheation or delivery of a document or radio or television broadcast. See Securities Act Rule 254(b)(4), 17 C.F.R. § 230.254(b)(4) (1999).

114. See Securities Act Rule 502(c), 17 C.F.R. $\$ 230.502$ (c) (defining solicitations to include "(1) Any advertisement, article, notice or other communication published in any newspaper, magazine, or similar media or broadcast over television or radio; and (2) Any seminar or ineeting whose attendees have been invited by any general solicitation or general advertising"); see also In the Matter of Kenman 
sell only to those investors with whom they have a preexisting relationship. ${ }^{115}$ As a result, brokers often prescreen investors, thereby maintaining pools of investors with a preexisting relationship. Issuers then seek the services of such brokers, in part, to access the brokers' lists of prescreened mvestors. ${ }^{116}$ Prescreening through brokers, however, is inferior to the extent that brokers have an incentive to qualify investors improperly as a means to increase their investor base. In addition, because broker prescreening is decentralized and applies only to private placements, this mechanism provides little feedback to the market on the state of investor knowledge and the need for particular types of investor safeguards.

A criticism of this Article's self-regulatory proposal for issuer-, intermediary-, and aggregate-level investors is that many investors are not rational and face cognitive problems in determining their own level of mvestment knowledge. ${ }^{117}$ For instance, investors may engage in loss avoidance, meaning that they are more concerned with doing worse than doing better relative to an expected benchmark. Drawing on the concept of loss avoidance, Professor Donald Langevoort has argued that investors who lose money im the niarkets may engage in super-risky investments in an attempt to erase their losses. ${ }^{118}$ On the other hand, investors may act with overconfidence, placing too little weight on low-probability risks and justifying their prior decisions even when misguided. ${ }^{119}$ One example of the problems that arise from irrational investor behavior is that intermediaries faced with irrational investors may attempt to develop trust; intermediaries then have an mcentive to defraud investors to the extent irrational investors place too much reliance on this trust. ${ }^{120}$ Therefore, investors

Corp., Exchange Act Release No. 21,962, [1984-85 Transfer Binder] Fed. Sec. L. Rep. (CCH) 83,767 (April 19, 1985) (holding that an offering solicitation sent to an unknown number of persons was a general solicitation for purposes of Rule 502(c)).

115. The SEC has indicated that for Rule 502(c) of the Securities Act,

[t]he types of relationships with offerees that may be important in establishing that a general solicitation has not taken place are those that would enable the issuer (or a person acting on its behalf) to be aware of the financial circumstances or sophistication of the persons with whom the relationship exists or that otherwise are of some substance and duration.

SEC No-Action Letter, Mineral Lands Research \& Marketing Corp., Nov. 4., 1985.

116. See, e.g., Langevoort, supra note 36, at 4-12.

117. See Donald C. Langevoort, Selling Hope, Selling Risk: Some Lessons for Law from Behavioral Economics About Stockbrokers and Sophisticated Customers, 84 CALIF. L. REv. 627, 63541 (1996); see also Christine Jolls et al., A Behavioral Approach to Law and Economics, 50 STAN. L. REv. 1471 (1998) (describing behavioral economics and its relationship to the law).

118. See Langevoort, supra note 117 , at 638.

119. See id. at 639. Similarly, investors may act with "hindsight bias," placing too much weight on past performance in projecting future performance. See, e.g., Jonathan Clements, Riskphobes are Taking Two Big Gambles, WALL ST. J., Dec. 1, 1998, at C1.

120. See Langevoort, supra note 117, at 655 ("The principle of cognitive dissonance makes plain that once committed, customers will resist the notion that they are being exploited."). On the other hand, Langevoort argues that even professional money managers suffer from such behavioral irrationalities. See id. at 643-45. Professional money managers, for example, may care about falling 
acting irrationally will not correctly value investor protection devices. ${ }^{121}$ Critics may also argue that mvestors with cognitive biases may self-license into an improper investor group. Intermediary-level investors, for example, may overoptimistically call themselves issuer-level informed.

As with access to information, the amount of cognitive dissonance afflicting an mvestor may vary. ${ }^{122}$ Cognitive dissonance is likely to be correlated with an investor's investment experience. More experienced mvestors will have a greater number of reference points by which to measure their investing acumen, leading to imcreased rationality in the voluntary licensing process. Greater market experience, in addition, provides investors the opportunity to learn and correct their individual cogmitive biases..$^{123}$ Allowing at least those investors with a minimum level of market experience to determine their investor protections, therefore, may still maximize the welfare of more sophisticated investors relative to the current regulatory regime. ${ }^{124}$

This Article's proposal, in addition, focuses on determining investor knowledge not at the time of any particular transaction but rather before any investment transactions commence. As a result, many of the biases from cognitive dissonance are reduced. ${ }^{125}$ Investors who have not yet made any investment decisions will not suffer from a bias to support the status quo. Nor will they have any predisposed optimism with respect to any particular market intermediary or issuer at the time of certification. The

behind their peer groups to the extent their compensation, social status, and self-image are based on their relative performance. See id.

See also Donald C. Langevoort, Behavioral Theories of Judgment and Decision Making in Legal Scholarship: A Literature Review, 51 VAND. L. REv 1499, 1501 n.6 (1998) [hereinafter Langevoort, Behavioral Theories] ("Cognitive dissonance is a basic concept in social psychology, referring to the tendency of people unconsciously to adjust their attitudes and beliefs to conform to voluntary choices previously made." (citing Elliot ARonson, The Soctal ANimal (7th ed. 1995))).

121. Commentators, as a result, argue for placing mandatory duties on intermediaries. For example, Langevoort would impose more obligations on brokers to the extent they develop trust with their investor-clients. See Langevoort, supra note 117, at 688-95.

122. See Langevoort, Behavioral Theories, supra note 120, at 1501 n.6 (defining cognitive dissonance).

123. But see Langevoort, supra note 117, at 639 ("People dwell on successes and attribute them to skill and diligence. Failures are more readily dismissed as the product of chance and other unforeseeable external causes.").

124. See supra Part I.A.6 (discussing problems in the present regime).

125. Nevertheless, shifting to an investor regulation system today would mean that investors with varying degrees of prior experience would suddenly have to make a decision about low to license themselves. Some investors may therefore already be in the midst of making an investment decision when they seek their initial investment licensing level, leading to possible cognitive biases such as overconfidence. These costs, however, would be onetime at the start of an investor regulation regime. As well, once an investor regulation regime is underway, regulators may reduce the possibility of investors seeking a particular licensing level in order to make a specific investunent through the use of waiting periods. 
licensing process itself may warn investors of the possibility of different biases including, for example, hindsight bias. ${ }^{126}$

The present regulatory regime relies primarily on disclosure and therefore is equally vulnerable to cognitive problems investors face in processing the disclosed information. ${ }^{127}$ Where investors suffer from irrational biases in their decision making, increasing disclosure of raw company-related information alone will not result in rational decisions. This is particularly true for less sophisticated investors with inadequate experience to assess disclosed information. Moreover, investors prone to cognitive biases may also overestimate how much protection government regulations provide. Removing mandatory regulatory protections and forcing more sophisticated investors to confront choices in the protections they receive helps to mitigate these cognitive biases and may lead to better valuation of investor protections.

Even with a well-functioning voluntary licensing system, some investors might remain overly optimistic about their own abilities. Investor regulation might fail to identify such investors, and the market would therefore provide suboptimal levels of investor protection. Nevertheless, the danger from cognitive dissonance must be weighed against the benefit from providing market discipline in determining investor protections. This, together with the high cost of remaining with the present regime, which is itself plagued with cognitive bias problenıs, supports investor regulation.

\section{Hybrid Licensing Schemes}

Given the potential problems with both mandatory and voluntary licensing, soine combination of the two systems may result in the most accurate investor screening. Several combinations are possible. For example, a voluntary licensing regime may benefit from certain mandatory aspects. As discussed above, voluntary licensing inay work better for investors with more market experience. Regulators could impose a waiting period for investors to move from aggregate-level to intermediary-level

126. See Langevoort, supra note 117, at 629 n.4 (defining hindsight bias as "the natural tendency to overweight the probability that an event would come to pass after one is told that later it did come to pass").

127. Langevoort recognizes the possibility that cognitive biases may make mandatory disclosure ineffective. See Langevoort, supra note 36 , at 23 "'We might discover that the investment process is less than fully rational, but that our traditional form of regulation-mandatory disclosure-adds less of value than we think, precisely because other influences dominate the decision-making process.").

Regulators also may suffer from cognitive biases, imposing higher levels of securities regulation when markets drop in value, to protect investors, while ignoring the benefits to investors when the market increases in value. Over the past 300 years, most waves of new securities regulation have occurred after a sustained price decline in the stock market. See Stuart Banner, What Causes New Securities Regulation?: 300 Years of Evidence, 75 WASH. U. L.Q. 849, 850 (1997). 
and eventually to issuer-level. Investors could be made to wait one year before they may imcrease their licensing level. ${ }^{128}$

Alternatively, regulators could employ a mandatory licensing regime that gives investors some confined ability to select their proper license level. For example, in the case of investor licensing, errors of underinclusion are more costly than overinclusion. Where well-informed investors fail to receive a particular licensing level (an error of underinclusion), they are prohibited from entering into certain types of investments despite their qualifications. Well-informed investors, therefore, might lose valuable investment opportunities indefinitely. On the other hand, where lessinformed investors receive too advanced a license in error, the market can work to correct the overinclusion. First, such investors imght realize through the educational component of the licensing process that they are not qualified and voluntarily choose not to trade based on the full extent of their licensed privilege. Second, mistakenly licensed investors will receive systematically worse investment performance over time, leading them either to exit the market or to change their investment behavior to conform with a reduced level of licensing.

Given the asymmetry im error costs from mandatory licensing, regulators might choose to err on the side of overinclusion. For example, to achieve an aggregate-level license, regulators may design an exam that purposefully passes a relatively large percentage of underqualified investors. An overoptimistic investor might therefore end up with a higher-thanwarranted licensing level. Even in such situations, however, the magmitude of error would be less than under a completely voluntary system. Where investors have complete freedoin of choice, an unsophisticated investor could freely select an issuer-level license. Under a mandatory licensing scheme skewed toward erring on the side of overinclusion, the same unsophisticated investor might successfully achieve an aggregate-level license but would most likely not obtam any higher license level. ${ }^{129}$

\section{Third-Party Regulations}

In addition to protecting imvestors, a second goal of the existing regulatory regime is to address the third-party effects of securities transactions. This Section describes the various types of third-party effects and the ways in which these are addressed by the existing regulatory scheme. In addition, this Section explams how mvestor regulation has the potential both to

128. A mandatory waiting period would nevertheless result in inefficiencies. For example, investors truly capable of assessing investment risk lose the ability to engage in desired investments during the waiting period. On the other hand, the inefficiency cost must be balanced against the benefit of inore accurate investor classification.

129. This assunes that despite erring on the side of overinclusion, exams for progressively higher hicense levels still become progressively more difficult to pass. 
minimize negative third-party effects and to allow regulators to focus more on third-party protections.

First, when parties engage in a transaction, one or both of the parties may make a bid or ask quotation. ${ }^{130}$ Information on bid-ask quotations, as well as on prices and quantities of completed transactions, is valuable not only to the parties in a particular transaction, but also to the rest of the market. Through quotations, transaction prices, and volume information, the market receives a signal on how investors value a particular security. For example, when the market learns that a large mutual fund is engaged in high-volume purchases of a particular company's stock at a premium, other market participants may increase their valuation of the stock. ${ }^{131}$ Transacting parties, however, do not fully capture the information benefit from their particular trade, and therefore, may not have full incentives to transmit this information to other market participants.

In response, the SEC has worked to increase price transparency across the market for different transacting parties. ${ }^{132}$ Rules $11 \mathrm{Ac1}-1$ and $11 \mathrm{Ac} 2-2$ of the Exchange Act impose an obligation on market makers and specialists in exchange-listed or National Market System securities to report immediately to a consolidated quotation system any changes in bid and ask quotations. In addition to the obligations directly imposed on market makers and specialist broker-dealers, the SEC has also sought to create communication linkages between different market centers, increasing the ability of brokers and investors to execute at best possible prices. Registered exchanges, for example, must become participants in the linkages

130. The bid price is the price at which a potential buyer for a security would be willing to make a purchase. The ask price is the price at which a potential seller of a security would be willing to make a sale. Certain dealers specialize in making a market for NASDAQ-listed securities, holding themselves out continuously as willing to purchase a security at a quoted bid price and to sell the same security at a quoted ask price. Such market-making dealers earn a profit from the spread between the lower bid price and the higher ask price.

131. The process by which the market price incorporates new information is termed "price discovery." Joel Hasbrouck, One Security, Many Markets: Determining the Contributions to Price Discovery, 50 J. FIN. 1175, 1175 (1995). Hasbrouck provides evidence that the NYSE is responsible for most of the trades leading to price discovery in 30 Dow stocks listed on the NYSE, despite the fact that the NYSE accounts for a far sinaller percentage of total trading volume. See id. Hasbrouck's findings support the contention that third market dealers in NYSE-listed stocks free-ride off of the NYSE's price discovery function. But see Hans R. Stoll, The Causes and Consequences of the Rise in Third Market and Regional Trading, 19 J. CoRP. L. 509 (1994) (arguing that fragmentation in markets, including the presence of third market makers in NYSE listed stocks, results in beneficial competition and imcreases price continuity).

132. Among other problems, the SEC has stated that market fragmentation places a lower incentive on market makers to reduce their overall price spread, hurting competition and raising market maker profits at the expense of small retail investors. See Aircraft Carrier Release, supra note 68, at 1436-37 \& n.86. As well, market fragmentation increases the cost to other brokers in determining the best price for orders and slows down the incorporation of new information into the market price. See Exchange Act Release No. 13,662, 42 Fed. Reg. 33,510 (1977) (to be codified at 17 C.F.R. pt. 240). 
created under the National Market System, including the Intermarket Trading System (ITS). ${ }^{.33}$

Second, investors benefit from liquidity. ${ }^{134}$ Liquidity provides investors the ability to purchase or sell a particular security quickly and at a low transaction cost. ${ }^{135}$ It also reduces the risk to market makers that they will be unable to cover their purchase or sell orders, which in turn decreases the bid-ask spread. ${ }^{136}$ All else being equal, securities of issuers with more liquidity therefore enjoy a higher market price. ${ }^{137}$ The degree of liquidity in a particular market depends in part on the volume of the market. ${ }^{138}$ The greater the number of investors trading in a security, the less likely an order imbalance will result. Order imbalances hurt liquidity to the extent potential buyers (or sellers) are unable to find an opposite party willing to engage in a transaction at a particular market price. Individual investors, however, ignore the benefit their presence in the market has on increasing liquidity for third parties. Put another way, a single investor could help alleviate an order imbalance where too many sellers are present in the market relative to buyers (or vice versa) by choosing to buy some securities at a given market price (or to sell in the reverse situation). No single investor,

133. The ITS provides a communication system for broker-dealers to execute trades in competing linked market centers. In addition to the ITS, the Consolidated Tape Association (CTA) and the Consolidated Quotation System (CQS) also are part of the National Market System. The CTA consohdates last sale information for certain listed stocks and disseminates this information to vendors and other subscribers. The CQS consolidates quotation information from market makers in listed securities and disseminates this imformation to vendors and other subscribers. See, e.g., Securities Exchange Act Release Nos. 37191 (May 9, 1996), 61 Fed. Reg. 24842 (May 16, 1996); 28874 (Feb. 12, 1991), 56 Fed. Reg. 6889 (Feb. 20, 1991) (Chicago Board Options Exchange / ITS linkage); 23365 (June 23, 1986), 51 Fed. Reg. 23865 (July 1, 1986) (Cincinnati Stock Exchange / ITS linkage); 18713 (May 6, 1982) 47 Fed. Reg. 20413 (May 12, 1982) (NASD's CAES / ITS linkage); 17532 (Feb. 10, 1981), 46 Fed. Reg. 12919 (Feb. 18, 1981). See generally Joel Seligman, The Future of the National Market System, 10 J. CORP. L. 79, 82-92 (1984) (describing the formation of the National Market System).

134. Professors Macey and Haddock define liquidity as "a market characteristic that assures investors that they can promptly dispose of or purchase securities at a price reasonably related to the immediately preceding price for that security and to the anticipated succeeding prices." Jonathan $\mathrm{R}$. Macey \& David D. Haddock, Shirking at the SEC: The Failure of the National Market System, 1985 U. ILL. L. REv. 315, 325 (1985).

135. But see Lynn A. Stout, Technology, Transactions Costs, and Investor Welfare: Is a Motley Fool Born Every Minute?, 75 WASH U. L.Q. 791, 792, 796-804 (1997) (arguing that reduced transaction costs due to the Internet may increase the amount of "speculative" trading resulting in greater researcl and overall broker's commissions without increasing net investor welfare).

136. The bid-ask spread constitutes the primary way market makers earn a return for their service of providing market liquidity. Where the market is illiquid to begin with, market makers must compensate for the higher cost of providing liquidity through a greater bìd-ask spread.

137. See Amihud \& Mendelson, supra note 19, at 1428.

138. Liquidity also depends on the willingness of market participants to publicize bid-ask quotations for a security. For several reasons, the present regime may discourage such quotations. In particular, to the extent the Intermarket Trading System allows market makers based on other trading centers to free-ride off of another's quotations-matching the quotation when beneficial and passing the order onto the market maker making the original quotation-no one lias an mcentive to make a quotation. See id. at 1433-39. 
however, has full incentives to take such an opposite position to an order imbalance when other investors also capture the benefit froin the resulting increase in liquidity. In response, the SEC adopted Rule 11b-1 under the Exchange Act, forcing exchanges to require specialist broker-dealers to conduct trades to "assist in the maintenance, so far as practicable, of a fair and orderly market" and to refrain froin dealings that may inpair such a fair and orderly inarket. ${ }^{139}$

Third, increased competition across different trading venues benefits all investors, increasing execution speed and reducing trading costs. However, if no single investor captures the entire benefit froin increased competition, individual investors may not push for competition. To increase coinpetition between alternative trading systems and exchanges, the SEC promulgated special order handling rules in 1996. ${ }^{140}$ Among the requirements are that market makers and specialist broker-dealers inake publicly available any superior quotations they inake through electronic communication networks. ${ }^{141}$

Fourth, transactions designed to manipulate the market price affect many third parties. For exaniple, a manipulator nay enter into a series of purchase transactions designed to create an atmosphere of interest around the security. Parties that sell their securities to the manipulator are not necessarily harmed; they receive an inflated price for the securities they sell to the manipulator. A manipulator may even sell securities to herself, taking both sides of a transaction. ${ }^{142}$ However, subsequent purchasers of the security buy at an inflated price and are therefore harmed by the frenzy caused by the manipulator's initial purchases. Because the subsequent purchasers are not in a direct contract relationship with the manipulator, the manipulator will not be deterred by the loss to subsequent purchasers. In addition to specific prohibitions contained in Section 9(a) of the Exchange Act, Section $10(\mathrm{~b})$ of the Exchange Act grants the SEC the power to prohibit by

139. Exchange Act Rule 11b-1(a)(2)(ii), 17 C.F.R. $\S 240.11 b-1$ (1999). In response, the NYSE imposed Rule 104 on its specialist broker-dealers requiring specialists, among other things, to "engage to a reasonable degree ... in dealings for his own account when lack of price continuity, lack of depth, or disparity between supply and demand exists or is reasonably to be anticipated." N.Y.S.E. Guide (CCH) II 2104 (Nov. 3, 1986). But see Macey \& Kanda, supra note 18, at 1012-20 (arguing that liquidity is largely endogenons from the perspective of exchanges, depending mostly on the amount of information flow from issuers and market capitalization, and therefore that exchanges cannot improve liquidity much through regulations placed on specialists).

140. See Securities Exchange Act Release No. 37,619A, 61 Fed. Reg. 48,290 (Sept. 12, 1996) (to be codified at 17 C.F.R. pt. 240).

141. Electronic communication networks include any automated trading mechanism that disseminates market maker orders widely to third parties and also allows such orders to execute within the network, excluding systems which only cross orders without establishing a price. See id.

142. Such sales are termed "wash sales." The present regime prohibits wash sales under Section 9(a)(1) of the Exchange Act. See Exchange Act § 9(a)(1), 15 U.S.C. § 78i (1994). 
rule any "manipulative or deceptive device or contrivance" dealing with any security. ${ }^{143}$

Finally, commentators have expressed concern that excessive volatility across market centers may cause extreme price drops in certain situations. ${ }^{144}$ Individual trades adding to volatility impose a negative externality on all other market participants. In response, the SEC and other regulators have supported the use of trading halts to calm markets in times of extreme volatility. ${ }^{145}$ After the October 1987 stock market crash, both stock and futures exchanges adopted circuit breaker rules, halting trading after specified drops in index prices. ${ }^{146}$ The NYSE currently imposes a trading halt for increasing amounts of time if the Dow Jones Industrial Average drops more than ten percent, twenty percent, and thirty percent. ${ }^{147}$

Where externalities exist, Congress and the SEC may increase market welfare through targeted mandatory regulations aimed at increasing price transparency and market liquidity, as well as deterring market manipulation. Regulators, however, may make mistakes. Where regulators require different securities markets to link their quotation and execution services, for example through the Intermarket Trading System, ${ }^{148}$ they force different market centers to integrate quotations when such linkages may not maximize overall investor welfare. Professors Amihud and Mendelson, among others, argue that linkages allow smaller market centers to free-ride off price quotations made in larger markets such as the NYSE. ${ }^{149}$ As a result, specialists in the NYSE may not have full mcentives to reduce their

143. Exchange Act $\S 10(\mathrm{~b}), 15$ U.S.C. $\S 78 \mathrm{j}(\mathrm{b})$.

144. See Marcel Kahan, Securities Laws and the Social Costs of "Inaccurate" Stock Prices, 41 DukE L.J. 977, 995-96 (1992) (noting that "[o]ne reason for excess market volatility could be liquidity crunches. A sudden rush by investors to sell a large amount of stock may result in transient crashes: If the market lacks adequate liquidity to absorb the sales pressure rapidly, stock prices would temporarily fall below their fundamental value, and climb back to that value as investors obtain access to sufficient cash").

145. See, e.g., The Presidential Task Force on Market Mechanisms, Report 66 (1988). This report stated that

[c]ircuit breakers have three benefits. First, they limit credit risk and loss of financial confidence by providing a 'time-out' amid frenetic trading to settle up and ensure that everyone is solvent. Second, they facilitate price discovery by providing a 'time-out' to pause, evaluate, inhibit panic, and publicize order imbalances to attract value traders to cushion violent movements in the market. Finally, circuit breaker mechanisms counter the illusion of liqnidity by formalizing the economic fact of life ... that markets have a limited Id. capacity to absorb massive one-sided volume.

146. See Louis Loss \& Joel Seligman, Securities Regulation 2499 n.64 (3d ed. 1990).

147. See N.Y.S.E. Guide (CCH) II 2080 (Oct. 19, 1988); NYSE Information Memo 98-15 (1998).

148. See supra text accompanying note 133.

149. See Amihnd \& Mendelson, supra note 19, at 1434-36. For an earlier discussion of this point see David A. Lipton, Governance of Our Securities Markets and the Failure to Allocate Regulatory Responsibility, 34 CATH. UNIV. L. REV. 397, 410 (1985). 
bid-ask spread to the extent other market centers will mimic such reductions. ${ }^{150}$

The very act of regulation may hinder private market efforts to internalize the impact on third parties. Intermediaries, for example, may choose not to invest in creating mechanisms to protect third parties where regulators may supplant such mechamisms at any time with alternate solutions. ${ }^{151}$ Without regulatory interference, the market may very well work to internalize many of the externalities identified above. For example, to the extent investors are fearful of market manipulation, exchanges and other centralized intermediaries may voluntarily adopt rules against manipulation. Doing so increases the value to investors from trading on the particular exchange; the exchange benefits as its liquidity increases, and its broker-dealer members receive greater transaction volume. ${ }^{152}$ Likewise, issuers may internalize the benefit from increased liquidity in the issuers' securities, leading them to use this Article's self-tailored regulation proposal to limit trading in an issuer's securities only to certain liquid markets.

In addition, innovation spurred through a free-market system for investor protections may lead more intermediaries to becoine entrepreneurial with respect to third-party effects. Intermediaries who are already collaborating to provide low-cost investor protections might also coordinate to construct safeguards aimed at third-party effects. For example, an entrepreneurial securities exchange may attempt to coordinate with other exchanges to provide for rapid quotation and transaction price and volume information dissemination to investor-clients of the participating intermediaries.

150. Amihud and Mendelson write:

[A] dealer in one market can offer to execute orders at the price quoted in another market without the need to attract investors' orders by quoting better prices. Within the exchanges, however, incoming orders are executed according to price priority and then by time priority. Though this provides an incentive to quote early and stand ready to provide liquidity, the price priority and time priority incentives are circumvented by the ability in each market to match the quoted prices of the best markets. This reduces the incentive to provide liquidity to the inarket.

Amihud \& Mendelson, supra note 19, at 1435.

One solution to free-riding on NYSE quotations is to introduce a "universal message switch" that would connect the quotations of different market centers and give priority first to price and then to the time the order was placed in directing orders. Dealers would then have an incentive to put in lower quotes quickly to obtain time priority in receiving order flow. See, e.g., Seligman, supra note 133, at 133-37. Alternatively, Amihud and Mendelson propose allowing issuers to determine in which market centers their securities may trade. Competition among market centers for issuers then will generate trading rules and market linkages that maximize the welfare of particular issuers. See Ainihud \& Mendelson, supra note 19 , at 1445-46.

151. See Lipton, supra note 149, at 420-21 (noting that "self-regulatory bodies might hesitate to expend the resources necessary to develop an effective all market trading surveillance system knowing that the Commission might at some point either direct the creation of a surveillance system with specified capabilities or develop such a system on its own").

152. Alternatively, for a privately owned trading system, the trading system benefits through the ability to charge higher fees for investors seeking to use the system as a trading site. 
Where the market is unable to fully internalize third-party effects even under investor regulation, some mandatory regulatory response may be necessary. Nevertheless, investor regulation provides some insight into how the government should structure this mandatory regulation. In particular, many market externalities are not unique to specific types of intermediaries. Whether investment advisors, broker-dealers, or exchanges are involved in a transaction, the market benefits from increased price transparency. Likewise, all types of intermediaries may engage in market nianipulation. For third-party regulations, therefore, regulators should consider employing a particular form of functional regulation: ${ }^{153}$ regulation based on the risk presented to third parties. ${ }^{154}$ This third-party riskfunctional approach would have many positive points. Rather than have multiple regulations dealing with similar services provided through different types of intermediaries, regulators could develop one consistent approach. ${ }^{155} \mathrm{~A}$ consolidated approach creates economies of scale to the extent designing and implementing new regulations takes time and resources. Duplicated record keeping, monitoring, and enforcement costs would also be minimized.

Allowing the vast majority of regulations aimed at mvestor protection to be determined through the market under this Article's investor regulation proposal, moreover, strengthens the ability of regulators to apply functional regulation for third-party externalities. Focusing only on thirdparty protections would reduce the number of possible risks that regulators must monitor. Regulators, for example, could focus on price transparency, liquidity, market mampulation, volatility, and competitive third-party risks. With this narrow focus, regulators might design more efficacious regulations. Moreover, fewer regulations would result in greater certainty on the part of market participants as to what regulations their activities may coine under. Market participants would not need to worry about their classification as a certain type of regulated entity, such as a broker-dealer or exchange; rather, all that matters is whether the intermediary's activities give rise to one of the regulated third-party risks. Thus, investor regulation could reduce current market externalities, and at the same tinie, allow

153. See Heidi Mandanis Schooner, Regulating Risk Not Function, 66 U. CIN. L. REv. 441, 45759 \& n.123-24 (1998) (citing several commentators who support functional regulation in the banking and securities area); Alan Greenspan, Chairman, Board of Governors of the Federal Reserve System, Remarks Before the 31st Annual Conference on Bank Structure and Competition (May 11, 1995) (describing functional regulation "as a system in which each separate 'function'-such as commercial banking, investment bankiug, or mortgage banking-is supervised by the same regulatory body, regardless of the function's location within a particular financial institution").

154. Cf. Schooner, supra note 153 (arguing that regulators should move toward regulating banking activity based on risks posed to the FDIC system, investors, and the financial systein).

155. See, e.g., id. at 459 (noting that consistency "provides a level playing field to institutions operating within the industry and consistent protections to consumers"). 
regulators to focus on those externalities for which government regulation is truly necessary.

II

\section{Alternative Reform Proposals}

The securities regulatory regime has come under much scrutiny over the past several years. Even the SEC has recently considered radically changing the regulations governing public offerings. ${ }^{156}$ This Part assesses both SEC and academic proposals to reforn the securities laws in light of this Article's mvestor-regulation proposal.

\section{A. The SEC's Aircraft Carrier Release}

One demonstration of the relevance and value of this Article's proposal is the SEC's recent proposal to reforn the public offering process as described in its recent "Aircraft Carrier" release. ${ }^{157}$ Under the present rules, issuers conducting a public offering must follow a tightly controlled process, commonly referred to as the gun-jumping rules, designed to narrowly restrict issuer communication with potential investors. ${ }^{158}$ Under these rules, issuers generate and distribute information to the public through an administratively defined document known as the registration statement. ${ }^{159}$ The gun-jumping rules divide public offerings into three periods: the prefiling, waiting, and posteffective periods. ${ }^{160}$ During the prefiling period, issuers are restricted from inaking oral or written offers. ${ }^{161}$ After filing a registration statement with the SEC, issuers enter into the waiting period during which issuers may distribute only a preliminary prospectus. ${ }^{162}$ After twenty days, or sooner if the SEC accelerates its review process, the registration statement becomes effective and sales may commence. ${ }^{163}$ Issuers $m$ the posteffective period must distribute the final prospectus concurrent or prior to any other written communication offering to sell the

156. See, e.g., Aircraft Carrier Release, supra note 68.

157. See id.; see also Jeffrey Goldfarb, Registration of Securities: SEC Staffers Meet Publicly with Industry for First Time on "Aircraft Carrier" Proposal, 30 Sec. Reg. L. Rep. (BNA) 1631, (Nov. 13, 1998) (reporting on the Aircraft Carrier release).

158. See Stephen J. Choi, Company Registration: Toward a Status-Based Antifraud Regime, 64 U. CHI. L. REv. 567, 605-06 (1997) (describing the gun-jumping rules).

159. See supra note 3.

160. See Securities Act $\$ 5,15$ U.S.C. $\$ 77 e$ (1994) (providing the statutory framework for the gun-jumping process).

161. See Securities Act § 5(c), 15 U.S.C. § 77e(c); see also Securities Act § 2(a)(3), 15 U.S.C. § $77 \mathrm{~b}(\mathrm{a})(3)$ (defining "offer" to include solicitation of an offer).

162. See Securities Act $\S 5(b)(1), 15$ U.S.C. $\S 77 \mathrm{e}(\mathrm{b})(1)$ (prohibiting the transmission of a nonSection 10(b) preliminary prospectus); Securities Act $\S 2(10), 15$ U.S.C. $\S 77 b(a)(10)$ (defining "prospectus").

163. See Securities Act $\S 8(a), 15$ U.S.C. $\S 77$ h(a). 
securities. ${ }^{164}$ In addition, the prospectus must accompany any written confirmation of sales. ${ }^{165}$

Although considered radical, ${ }^{166}$ the reforms in the Aircraft Carrier release maintain the SEC's focus on regulating issuers. ${ }^{167}$ The release proposes to divide offermgs of securities into two categories: Form $A$ and Form B offerings. ${ }^{168}$ According to the SEC, "Form A offerings generally would be those made by smaller or unseasoned companies. Form B offerings would be those made by larger, seasoned, well-followed issuers and those made to relatively informed or sophisticated investors."169

Form A largely duplicates the SEC's present offering disclosure structure. "Unseasoned" issuers conducting an Initial Public Offering (IPO) would have to follow the present Form S-1 disclosure requirements. ${ }^{170}$ More seasoned issuers would file similar information but have a

164. Section 5 of the Securities Act prohibits the transmission of any "prospectus" using interstate commerce after the filing of a registration statement with the SEC unless the prospectus meets the formal statutory disclosure requirements under Section 10 of the Securities Act. See Securities Act $\$$ 5(b)(1), 15 U.S.C. $\$ 77 \mathrm{e}(\mathrm{b})(1)$; Securities Act $\S 10,15$ U.S.C. $\$ 77$ j. Section 2(a)(10) of the Securities Act, in turn, defines "prospectus" broadly to include "any prospectus, notice, circular, advertisement, letter, or communication, written or by radio or television, which offers any security for sale or confirms the sale of any security...." Securities Act $\$ 2(a)(10), 15$ U.S.C. $\$ 77 b(a)(10)$,

The combination of these provisions works to ban effectively the transmission of all written material outside of a Section 10 statutory prospectus unless an exemption from the definition of a prospectus is found. Section $2(a)(10)$ provides such an exemption, stating

a communication sent or given after the effective date of the registration statement .... shall not be deemed a prospectus if it is proved that prior to or at the same time with such communication a written prospectus nieeting the requirenients of subsection (a) of section 10 at the time of such communication was sent or given to the person to whom the communication was made....

Securities Act $\$ 2(a)(10)(a), 15$ U.S.C. $\$ 77 b(a)(10)(a)$.

Such exempted written communication is commonly referred to as "free writing." See also IA Harold S. Bloomenthal, Going Public and the Public Corporation \$ 8.04 (West 1999) (noting that free writing is not decmed a prospectus during the posteffective period "provided it is accompanied or preceded by the final prospectus").

165. See Securities Act $\$ 5(b)(2), 15$ U.S.C. $\$ 77 \mathrm{e}(\mathrm{b})(2)$ (prohibiting sale of securities without accompanying or preceding a Section 10 (b) prospectus).

166. See Goldfarb, supra note 157 (reporting that SEC Commissioner Isaac Hunt expressed concern that "the SEC had not focused enough on preventing or policing fraud").

167. In addition to the reform proposals discussed here, the Aircraft Carrier release proposes to reform prospectus delivery requirements, see Aircraft Carrier Release, supra note 68, at 1499-1510; the regulation of underwriters, see id. at 1510-16; the integration of pubhic and private placeinent offerings, see id. at 1516-22; and Exchange Act periodic disclosure requirements, see id. at 1522-33.

168. See id. at 1432-33. In addition, a third category of offerings, Form C offerings, would relate to business combinations or exchange offers. See id.

169. Id.

170. See id. at 1460 (defining seasoned issuers as either "issuers that have been reporting under the Exchange Act for at least 24 months, if they have a public float of $\$ 75$ million or more" or "issuers that have been reporting under the Exchange Act for at least 24 months and have filed at least two annual reports"); see also Securities Act Form S-1, 17 C.F.R. \$ 239.11 (1999) (detaihing the disclosure requirements for securities registration for "registra[nts] . . . for which no other form is authorized or prescribed"). 
greater ability to incorporate information by reference. ${ }^{171}$ Compared with the present regime, all Form A issuers would enjoy a greater ability to use "free writing" communication in addition to the statutory prospectus. ${ }^{172}$ In particular, free writing would be permissible under the proposed regime anytime after the initial filing of the registration statement with the SEC. ${ }^{173}$ Under the current regime, issuers must wait until the registration statement is not only filed but has become effective. Under the current regime, issuers cannot engage in free writing until after the registration statement has becoine effective. ${ }^{174}$ In addition, the proposal would allow certain seasoned Form $A$ issuers, including issuers with a public float of at least $\$ 75$ million, to determine for themselves the effective date of their offerings rather than wait for the SEC to accelerate the effective date of registration. ${ }^{175}$

In addition to the noderate changes contained in Form A, the Aircraft Carrier release's nost substantial changes revolve around proposed Form B. Through Form B, the SEC provides large and seasoned issuers greater control over the information they distribute to the public during a public offering. Under the proposed regime, Form B would be available to companies that the SEC determines inost likely trade in an efficient market, ${ }^{176}$ including companies with a public float of at least $\$ 250$ inillion, or a public float of $\$ 75$ million and an average daily trading volume of at least $\$ 1$ million. ${ }^{177}$ In addition, to qualify for Form B status, conipanies inust have at least one year of Exchange Act reporting experience. ${ }^{178}$

Under the SEC's proposal, Form B companies would face relaxed inandatory disclosure requirements. In particular, Form B issuers would not have to disclose general coinpany-related information in their registration statenients. Instead, information froin the issuers' recent periodic filings under the Exchange Act would be incorporated by reference into the prospectus. ${ }^{179}$ For transaction-related information, the SEC's proposal is open-ended, proposing alternatives ranging from requiring issuers to

171. See Aircraft Carrier Release, supra note 68 , at 1460.

172. Free writing consists of written communication other than the statutory prospectus that offers the securities for sale. See supra note 164.

173. See Aircraft Carrier Release, supra note 68, at 1460.

174. See Securities Act § 5(a), 15 U.S.C. \$ 77e(a) (1994).

175. See Aircraft Carrier Release, supra note 68, at 1462.

176. See id. at 1433 ("Because we believe that larger seasoned issuers attract a large market following and operate in an efficient market, we are considering providing them with a larger measure of flexibility to craft disclosure about their offerings.").

177. See id. at 1446 ("Our research indicates that companies that meet the proposed combined public float/[average daily trading volume] test would have an average of 14 analysts following them.").

178. In addition, Form B issuers must have filed at least one annual report with the SEC and must also have been timely in their Exchange Act filings within the 12 months prior to the filing of the registration statement. See id. at 1446-47.

179. See id. at 1441. In addition, Form B requires that the issuer incorporate the latest annual report into the registration statement. See id. 
comply with a reduced version of the present mandatory disclosure regime to allowing issuers to decide for themselves what transactional information the market would consider material. ${ }^{180}$

Under the Aircraft Carrier proposal, Form B issuers would also have greater control over when they may commence their public offering. Form $\mathrm{B}$ issuers would have the ability to declare a registration statement effective immediately upon filing or at any subsequent time that the issuers specify. ${ }^{181}$ Form $B$ issuers would also be exempt from the ban on prefiling offering communication under the gun-jumping rules. ${ }^{182}$ As a result, Form $B$ issuers may freely commumicate with potential imvestors and make offers prior to the filing of the registration statement. ${ }^{183}$ Form $B$ issuers, as well, may engage in free writing at any time during the offering period..$^{184}$

The Aircraft Carrier release's focus on regulating companies stems from an assumption that imvestors possess different amounts of information on particular companies. For large and seasoned Form B issuers, the release assumes that many analysts follow the companies. ${ }^{185}$ As a result, the companies' securities tráde on an efficient market, allowing even unsophisticated investors to rely on the securities market prices of large and seasoned companies to reflect all publicly-available information. For less well-followed companies, the rationale behind the efficient market hypothesis becomes weaker, and the Aircraft Carrier release reflects this through increased requirements for smaller and unseasoned issuers.

The SEC's Form B offering regime includes soine aspects that are similar to imvestor regulation. For example, Form B registration is available not only to large and seasoned issuers but also to other issuers that sell only to qualified institutional buyers, as defined by Rule $144 \mathrm{~A} .{ }^{186}$ In other words, the proposal allows investors with a high-level of sophisticationqualified institutional buyers (QIBs) - to purchase securities more easily

180. See id. at 1441-42.

181. See id. at 1443-44.

182. See Securities Act $\$ 5(c), 15$ U.S.C. $\$ 77$ e(c) (1994).

183. See Aircraft Carrier Release, supra note 68, at 1484. Even Form A issuers, under the Aircraft Carrier proposal, would be able to engage in prefiling communication without worrying about the SEC's ban on prefiling offers so long as the communications occur more than $\mathbf{3 0}$ days prior to the filing of the registration statement. See id. at 1485-86.

184. See id. at 1443 ("Free writing could include, but would not be limited to, sales literature and selling documents that include forward-looking information."). Only written communication not directly treated as an "offering communication" and occurring during the "offering period" may be treated as free writing for Form B issuers. The offering period is defined as the time period from " 15 days before the first offer made by or on behalf of the issuer and ending at the time of completion of the offering." Id. Form B issuers, nevertheless, must file the free writing with the SEC. See id. Section 12(a)(2) antifraud liability would also apply to the free writing. See id. at 1466.

185. See id. at 1446.

186. See id. at 1448; see also supra text accompanying notes 81-82. In addition, those issuers that qualify for Form B status have reported under the Exchange Act for at least one year, have filed an annual report, and have been timely and up-to-date in all filings. See id. 
from a range of potentially inefficient market issuers. The relaxed requirements targeted at large and seasoned Form B issuers, as well as at issuers selling to QIBs, is similar to this Article's use of the efficient market and investor knowledge in defining issuer-level investors.

Nevertheless, the Aircraft Carrier release suffers froin several flaws relative to an investor-regulation regime. First, investors are not given compete freedom of choice regarding the protections they receive. For example, although large and seasoned Form B issuers may make prefiling offers, they still are subject to antifraud liability. ${ }^{187}$ Issuers may consider antifraud liability costly to the extent that it gives rise to many frivolous lawsuits. However, under the current regime, issuers are unable to avoid this liability. As this Article has argued, however, where investors have issuer-level information, issuers should have the freedom to choose desired investor protections. For example, issuer-level investors could invest in an issuer eschewing any antifraud liability to avoid frivolous suits, relying instead on the issuer's reputation for quality to protect investors. Such investors may rationally choose to invest with such issuers in order to purchase the issuer's securities at a lower price.

Second, the SEC's recognition of the ability of QIBs to protect theinselves is also fiawed in light of this Article's proposed investor-regulation regime. The Aircraft Carrier release proposes to allow QIBs to resell securities immediately to the general public after an offering. ${ }^{188}$ Therefore, even unsophisticated investors could purchase securities of relatively unknown issuers indirectly through a QIB under the SEC's proposal. In contrast, investor regulation would impose firm limits on the investments that less sophisticated investors are allowed to make.

Third, the fact that an issuer's securities fail to trade on an efficient narket does not compel the conclusion that investors lack information on the company, and therefore must be protected by mandatory disclosure and other regulatory protections. Prices in an efficient inarket are not the only way for investors to value companies. As this Article has discussed, investors may individually research a company; ${ }^{189}$ in addition, investors may turn to intermediaries for investment assistance. ${ }^{100}$ Therefore, although the Aircraft Carrier release provides some relief froin regulation for large and seasoned companies, it does not go far enough where investors are

187. For example, Section 11 liability would continue to apply for material misstatements in the registration statement while Section 12(a)(2) liability would cover fraud in the prospectus, among other things. See id. at 1465-67.

188. See id. at 1448. To combat the possibility of QIBs acting as "conduits" to the general public, the SEC's proposal does restrict investment advisors and dealers from pureliasing a Form B QIB-only offering. See id. Nevertheless, through other QIBs, investors witl varying degrees of sophistication would still liave access to the securities of companies that do not trade on an efficient market.

189. See supra Part I.A.1.

190. See supra Part I.A.2. 
rational and well informed or associate with appropriate intermediaries to protect their interests.

Finally, the securities markets are dynamic and evolving rapidly. Giving investors the power to determine their own level of protection would allow market participants flexibility in providing value-maximizing investor protections. In addition, investors would have an incentive to learn inore about the market and increase their sophistication. As more investors become sophisticated, inarket participants will adjust their investor protections to target these investors. This Article's investor-regulation regime, unlike the reforms proposed under the Aircraft Carrier release, allows protections to evolve with the abilities of investors in the market.

\section{B. Other Market-Based Proposals}

In recent years, several academics have come forward with a variety of different inarket-driven proposals for securities regulation reform. For example, in a previous Article, Professor Andrew Guzinan and I put forward the concept of "portable reciprocity," arguing that issuers should have broad freedom to choose a regulatory regime, whether provided by domestic regulations, through a foreign government, or even through a private entity. ${ }^{191}$ In a conteinporaneous Article, Professor Roberta Romano set forth a reform proposal based on an analogy to state provisions of corporate law, arguing that inany aspects of securities regulation should follow a similar system. ${ }^{192}$ Under both proposals, issuers would have the freedom to choose among competing sources of securities regulation. To the extent investors are rational and informed, either directly or through an efficient inarket, they will price adopted investor protection accordingly regardless of the source of these protections. Issuers, in turn, will have an incentive to adopt protections investors value in order to increase the price they may obtain for their securities.

The investor-regulation model coinplements and refines the portable reciprocity reform proposal. For those companies that deal only with issuer-level investors, whether directly informed or through an efficient inarket, investor regulation mirrors portable reciprocity. The refinement comes in the recognition that not all investors are well-informed, and that not all companies trade in an efficient market. For such situations, investors may seek out alternative forms of protection; for example, intermediary level investors will seek protection through intermediaries. On the other hand, where investors completely lack information and are unsophisticated, this Article proposes mandatory restrictions on the ability of such investors to invest outside passive index funds. Taking into account different levels of investor sophistication applies the portable reciprocity

191. See Choi \& Guzmán, supra note 99.

192. See Romano, supra note 99. 
rationale where it works best, while also protecting those investors unable to fend for themselves.

In a recent Article, Professor Alan Palmiter argued for an alternative hybrid market-based system. ${ }^{193}$ Like the portable reciprocity proposal, Palmiter relied heavily on the ability of market forces to generate a desirable level of investor protection. Arguing that the SEC often makes uninformed regulatory decisions and is too rigid in its belief that investors are naïve and unable to value provided investor protections, ${ }^{194}$ Palmiter proposed that for primary securities offerings, issuers should have the ability to opt out of any mandatory disclosure requirement. ${ }^{195}$ In addition, Palmiter would also allow issuers to opt out of the antifraud provisions specific to primary offerings. ${ }^{196}$

However, Palmiter stops short of full opt-out in two ways. First, he suggests that all issuers, regardless of the presence of an efficient market and regardless of the sophistication of investors, should face Rule 10b-5 liability for their disclosures. ${ }^{197}$ However, if Rule $10 \mathrm{~b}-5$ is truly valuable enough to investors and flexible to meet a variety of needs, ${ }^{198}$ investors with information on this value will penalize issuers that do not adopt Rule 10b-5 through this Article's proposed self-tailored regulation. ${ }^{199}$ On the other hand, if investors are unsophisticated and lack the assistance of an appropriate intermediary, allowing issuers to opt out of mandatory disclosure invites fraud and poor investment decisions, regardless of the continued presence of Rule 10b-5. Key to the efficacy of Palmiter's proposal, therefore, are the types of investors in the market. To the extent a range of investors exist, this Article's emphasis on first determining investor capabilities and then applying appropriate regulations provides a superior means of regulation.

193. See Palmiter, supra note 17.

194. See id. at 23-27. In Palmiter's view, "[m]andatory disclosure assumes the SEC, in its various roles, will properly balance the benefits and costs of regulatory compliance. This may be too hopeful. Over time, the agency has been mesmerized by the regulatory syllogism, accepting the premise that issuers (unless compelled) will not disclose at levels sufficient for accurate pricing." Id. at 24.

195. See id. at $86-89$ (noting that issuers choosing to opt out of mandatory disclosure would be required to disclose this choice prominently to investors). In addition, Palmiter argues that the SEC should act as a source of possible securities disclosure forms, constantly adjusting the forms to fit the market demand. See id. at 95-97.

196. See id. at 92 ("Under my proposal, the issuer and other participants in a publie offering could choose not to offer investors the informational warranties now imposed by Section $11 \ldots$ and Section 12(a)(2).... Heightened hability would be broken out as an optional term-to be negotiated and priced separately.").

197. See id. at $92-95,130$.

198. Palmiter argues that $10 \mathrm{~b}-5$ rules are "implicit in all commercial transactions. Rules compelling issuer honesty may be essential even in situations of costless bargaining between wellinformed investors and competing issuers." Id. at 93. Palmiter also approves of court-based development of Rule 10b-5 doctrine. See id. at 132 (noting that "[t]he 10b-5 elements have become richly detailed and variegated").

199. See supra text accompanying notes 21-33 (describing self-tailored regulation). 
Second, Palmiter applies his market-based ideas only to primary offering disclosures, and not to mandatory periodic disclosures under the Exchange Act or other aspects of the securities regulatory regime. ${ }^{200}$ Nevertheless, to the extent an investor protection device aimed at the secondary market increases investor valuation of the security, knowledgeable investors take the presence of the secondary market protection into account in deciding how much to pay during a primary offering directly from the issuer. For example, an investor will not pay much to an issuer for a security that-because of a lack of secondary market protections-the investor will be unable to resell at a good price. ${ }^{201}$ To the extent issuers deal with knowledgeable investors at the time of their primary offering and want to obtain a high issue price, these issuers will adopt value-maximizing secondary market protections. Of course, this market mechamism depends on investor knowledge and highlights the importance of first distinguishing among investors in designing regulatory protections. ${ }^{202}$

\section{CONCLUSION}

The securities laws draw sharp distinctions among different types of issuers and internediaries. Investment advisors, broker-dealers, and exchanges, for example, are registered separately under the securities laws and face different qualification, capitalization, and disclosure requirements. In contrast, the present regulatory regime fails to differentiate among investors. This Article contends that regulators, rather than attempting to supplant the market, should focus on utilizing market-based efforts to correct defects in the capital markets. To this end, this Article proposes to

200. See id. at 91 . A company must register a class of equity securities (other than exempted securities) under the Exchange Act and accordiugly satisfy the periodic reporting requirements of Section 13(a) if (1) the company's total assets exceed $\$ 10$ million and (2) more than 500 shareholders hold, of record, the nonexempt class of securities. Exchange Act $\S 13,15$ U.S.C. § 78m (1994); see also, Exchange Act Rule 12g-1, 17 C.F.R. $\$ 240.12 \mathrm{~g}-1$ (1999) (raising the asset requirement to $\$ 10$ million). Companies filing a registration statement that becomes effective under the Securities Act must also subsequently comply with the periodic reporting requirements. Exchange Act $\S 15$ (d), 15 U.S.C. $\S 78$ o(d).

One problem with failing to remove Exchange Act periodic disclosure requirements is that those issuers with the least amount of market information gain the greatest freedom to deceive investors. Larger, more well-known issuers typically will fall under the Exchange Act's reporting requirements. Even if these issuers choose to opt out of all primary market disclosures under Palmiter's proposal, they still must disclose to the market and the SEC through the periodic information disclosure requirements. On the other hand, under Palmiter's proposal, at the time of their initial offer, sinall, unknown companies may escape disclosure requirements of both the Exchange Act as well as primary offeriugs. It is precisely for these sorts of companies, however, that relatively less sophisticated imvestors may fail to take into account the lack of information.

201. Where other investors in the secondary market are too fearful of fraud and the issuer adopts no antifraud protections for the secondary market through self-tailored regulation, for example, an initial investor may be unable to resell purchased securities without providing a significant discount.

202. Other authors have set forth variants of market-based investor protection. See supra note 55 and accompanying text (discussing securities exchange-based regulatory proposals). 
license investors and to tailor regulatory protections based on investor knowledge.

General financial knowledge is not necessarily crucial to investor protection. Instead, information on the range of market participants, the possible risks they pose to investors, and available investor protection devices afford investors a better opportunity to make informed investment decisions. Where investors lack direct information on particular securities but have good knowledge of different intermediaries, they may contract with a securities market intermediary to purchase expertise and guidance.

The objective of this Article has been to suggest a consistent and potentially more effective alternative to the present securities regime. Although this Article does not provide all the details of a fully functional regulatory system, it does establish a theoretical foundation for such a systein. Fnrther work is needed in order to make investor regulation operational. Some may criticize the investor-regulation proposal as too theoretical or impractical. However, many government agencies already use licensing. ${ }^{203}$ And although investor regulation may appear to be a radical shift, its operational structure is simple, allowing regulators to remove alınost all of the regulatory complexities of the Securities Act, the Exchange Act, the Investment Advisors Act, and the Investment Company Act. Moreover, the likely donestic and international benefits from introducing market forces into the provision of investor protection for those investors able to assess for themselves risks in the market, either directly or through intermediaries, supports a shift toward investor regulation.

203. See supra notes 107-08 (discussing FCC and FAA licensing procedures). 